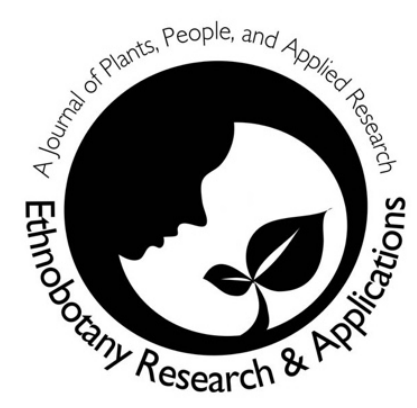

\title{
Diversity in the usages of edible wild plants by the Baka and Bakwélé in the periphery of the Tala Tala Forest Management Unit, North Congo
}

\author{
Jean Lagarde Betti, Rosine Liliane Kourogue, Faustine \\ Achuo Mbong, Pascal Eric Billong Fils, Oumar Farick \\ Njimbam Njukouyou
}

\section{Research}

\begin{abstract}
Background: In practice, timber companies use production forests or forest management units (FMU) for timber/wood purposes. Little attention is paid for Non-wood forest products (NWFP), which is not good. This study analyses the diversity in the usage of edible wild plants among the people based in the periphery of the Tala Tala FMU in the North Congo.
\end{abstract}

Methods: An ethnobotanical survey was conducted from 8 to 23 May 2012 on edible NWFP used by Baka and Bakwele populations living in the periphery of the Tala Tala FMU. The method used is the one called "Method for the popular usage», which consists of gathering data on the popular use of forest products in a given area. By comparing the Tala Tala whole population to a forest zone, it is possible to make reconciliations between the systematic botany and the ethnobotany. This reconciliation distinguishes five levels of data collection in the ethnobotany of the Tala Tala including the whole population, the ethnic group, the informant (household), the plant species, and the quotation. We assessed the relative importance, diversity, and similarities in the usages of edible NWFP.

Results: A total of 52 households provided information on the popular use of wild edible plants. A total of 57 plant species and 69 recipes were collected for which a total of 594 quotations (citations) were made. These plant species are distributed in 46 genus and 33 families. The Baka and Bakwélé communities use the same plant species and recipes in the same way and with the same importance. The overall usage diversity is higher for both plants and recipes $(H>4, E>0.8)$ among Baka pygmies than Bakwélé people.

Conclusions: Some plants used in the Tala Tala FMU are well known in other Congo basin countries for similar usages. Other were identified as "priority" or "key" edible NWFP. The glaring development challenge of what precedes is the urgent need to assess the abundance (availability) and conduct a structural analysis of the plant species used with the view to propose fair management schemes.

Keywords: Forest Management Unit, Non-Wood Forest Products, edible plants, recipes, ethnobotany, diversity indexes.

\section{Correspondence}

Jean Lagarde Betti, Rosine Liliane Kourogue, Faustine Achuo Mbong, Pascal Eric Billong Fils, Oumar Farick Njimbam Njukouyou

Department of Plant Biology, Faculty of Sciences, University of Douala, BP 24157 Cameroon, phone: 00 (237) 6773032 72/00 (237) 690343602

“Corresponding Author: lagardebetti@yahoo.fr

Ethnobotany Research \& Applications 19:09 (2020) 
Résumé

Diversité d'usage des plantes alimentaires sauvages chez les Baka et Bakwélé basées à la périphérie de I'Unité Forestière d'Aménagement de Tala Tala, dans le Nord Congo.

Introduction: En pratique, les compagnies forestières utilisent les forêts de production ou alors les unités forestières d'aménagement (UFA) pour l'exploitation du bois d'œuvre. Très peu d'attention est faite sur les produits forestiers non ligneux (PFNL), ce qui n'est pas bien. La présente étude analyse la diversité d'usages traditionnels des plantes alimentaires sauvages utilisées par les populations basées dans la périphérie de l'UFA Tala Tala, au Nord Congo.

Méthodes: Une enquête ethnobotanique a été menée du 08 au 23 mai 2012 sur les PFNL alimentaires utilisés par les populations Baka et Bakwélé qui vivent autour de I'UFA Tala Tala. La méthode utilisée pour la collecte des données est cele dite " méthode pour l'usage populaire » et qui consiste à interroger les villageois sur l'usage populaires des produits forestiers dans une zone donnée. En assimilant l'ensemble de la population vivant autour de I'UFA Tala Tala à une zone forestière, il est possible de faire des rapprochements entre la botanique systématique et l'ethnobotanique. Ce rapprochement permet de distinguer cinq niveaux en ce qui concerne la collecte des données ethnobotaniques à savoir: la population, le groupe ethnique, l'informateur ou le ménage, l'espèce végétale, et la citation. Nous avons apprécié l'importance relative, la diversité et les convergences d'emplois des PFNL alimentaires.

Résultats: un total de 52 ménages ont fourni 594 citations sur l'usage populaire des plantes alimentaires sauvages. Ces citations sont distribuées dans 69 recettes et font intervenir 57 espèces végétales distribuées dans 46 genres et 33 familles. Les communautés Baka et Bakwélé utilisent les mêmes plantes et recettes avec I même importance. La diversité globale des usages est plus élevée chez les pygmées Baka comparé aux Bakwélé $(H>4, E>0.8)$.

Conclusion: Certaines plantes utilisées à Tala Tala sont bien connues pour les mêmes usages dans d'autres pays du bassin du Congo. D'autres espèces citées ont déjà été relevées dans la littérature existante comme " espèces prioritaires » ou encore " espèces clés ». II importe de conduire des inventaires forestiers pour apprécier l'abondance ou le potentiel de ces espèces dans la forêt en vue de proposer des schémas d'aménagement pour leur utilisation durable.
Mots clés: Unité Forestière d'Aménagement, Produits forestiers non ligneux, plantes alimentaires, recettes, ethnobotanique, indices de diversité.

\section{Background}

In adhering to the Millennium Development Goals, most countries were committed to reduce global poverty by 2015 . It is among tropical forest dependent communities where poverty tends to be more diffuse and deeper than in more affluent urban areas. People living in forest areas in general, and indigenous people in particular, have depended for generations on harvesting various products from forests. Forests continue to play a role today in meeting the basic needs of the poor (Betti 2004, Tieguhong et al. 2012, Fungo et al. 2015).

The territory of the Republic of Congo has a significant forest cover estimated at $22.471,271$ hectares, which is about $69 \%$ of the national territory. This forest is distributed in three main blocs including the Mayombe massif $(1.500,000$ ha) located between the Congolese Littoral and the valley of Niari, the Chaillu massif $(4.500,000$ ha) located at the South West of Congo, and the massif of the North Congo (16.000,000 ha) bordering the Democratic Republic of Congo, Cameroon and Gabon. These forests are full of immense wealth which contributes to the social and economic development of the country. To prevent the degradation of forest ecosystems and promote the sustainable development, the Congolese Government defined a forest code in 1974. This code was considered at that time as the fair and coherent forest code in the Congo Basin range States. The 1974's forest code defined the FMU, the annual maximal volume (AMV), and the promotion of the local processing of timber. Since 2000, the Congolese forest sector is regulated by the law $n^{\circ} 16-2000$ of 20 November 2000 , which was modified by the law $n^{\circ} 14-2009$ of 30 December 2009 (Ministry of Forest Economy and Environment, 2004 ; 2005). This new forest code (policy) distinguished the Congolese forest in two main domains including the private forests and the state forests (Koubouana, 2017). State forests are themselves divided in two groups including the nonpermanent domain and the permanent domain. Nonpermanent domain is composed of protected areas, while permanent domain is made of production forests including FMU and forest plantations. The permanent domain totalizes 23.51, 493 ha, and is composed of 36 FMU and forest plantations (Eucalyptus sp., Pinus sp., Okoumea klaineana, and Terminalia superba). FMUs are vast forests of more than 100.000 ha, assigned to the sustainable production of the wood and other resources (nontimber forest resources for example) in respect to the conditions that allow the preservation of ecological 
functions of the forest (ACTED 2012; Betti et al. 2012; Koubouana 2017).

Tala Tala FMU is located in the northern part of the Congo. It is the combination of three main domain areas including: the west zone formerly attributed by the Congolese Government for forest logging to the "Société Congolaise Arabe Libyenne" (SOCALIB) timber company from 1986 to 1990, the center zone attributed to the "Société Forestière Algéro Congolaise" (SFAC) timber company from 1986 to 2003, and the area not yet attributed located at the Sembé - Souanké zone to be precise. The three domain areas have been attributed by the Congolese Government to a new timber company, the «Société Industrielle Forestière du Congo » (SIFCO) to be governed through the arrêté $n^{\circ} 5745 / M E F E / C A B$ of 19 September 2005. But it is only since 2007 that SIFCO starts working in the Tala Tala FMU, located at $150 \mathrm{~km}$ to the city of Ouesso (CAFRAM 2018).

Non-wood forest products (NWFP) are defined as products from a biological origin other than wood, coming from a natural or artificial forest (Anonymous 2005). Those local people leaving around the forest periphery are related to the use of NWFP. In practice, timber companies use production forests or FMU for timber/wood purposes. Little attention is paid for NWFP, which is not good. The awareness is growing that sustainable forest management should include measures for effective conservation and management of NWFP resources in order to meet the actual and future needs of local people. Moreover, the development of commercial extraction of NTFPs is often considered as a means of improving rural people's living standards, as well as a suitable approach towards forest conservation. Regardless of any commercialization potential, these resources are vital livelihood components for many forest dependent communities (van Dijk and Wiersum, 2004, Rist et al. 2011). Following existing national forestry legislations in the Congo Basin, forestry companies and local communities are collaborating to conserve species of local value (Tieguhong and Ndoye, 2007)

When allocating the FMU to a given company, a preliminary three years convention is signed between the Forest administration and the forest company. The terms of this preliminary convention precise that the forest company has to produce within the three-years of the convention and before the definitive convention has been signed, three types of documents in respect to the norms and rules indicated in the forest law, and including: a management plan for the whole concession (FMU), a five-years management plan (for the forest logging unit), and the operation plan of the first year of activity. At the end of the preliminary convention, a definitive convention is then signed between the forest Company and the Congo Government for a renewable period of 15 years. In addition to those documents, the Government requests the timber company to sign a Memorandum of Understanding (MoU) between the company and local communities who are leaving the periphery of the forest. That specific MoU known as "Cahiers de charges " states the rights and duties of each party (Ministry of Forest Economy and Environment 2004; 2005; Betti et al. 2012). For the case of NWFP, the MoU states that local communities are allowed to harvest NWFP according to rules of the document of the management plan of the forest. Those rules are supposed to organize the harvesting of NWFP in space and in time. The problem is that those rules are often defined on empirical data and not on scientific basis. The document of the management plan as well as the $\mathrm{MoU}$ are both often imprecise on the list and characteristics of NWFP authorized to be harvested by local people. The spatial and temporal context of resource use by communities (including traditional usages, floristic and structural characteristics) needs to be taken into greater account in the revision of logging and silvicultural practices. While scientific understanding regarding the ecology and use of many locally consumed NTFPs remains superficial, much local knowledge on the autecology of individual species, the spatial and temporal context of their use and the differing modes of impact from logging may be available and should be more frequently drawn upon (Rist et al., 2010, 2011)

Since March 2010, the Cameroon Forest Resources Assessment and Management (CAFRAM), a forestry consulting company based at Yaounde, Cameroon, is assisting SIFCO in the elaboration of the management plan of the Tala Tala FMU. To this end, CAFRAM has engaged many studies including timber and NWFP inventories, wildlife census as well as ethnobotanical and socioeconomic inquiries. The present work is conducted in the frame of ethnobotanical studies defined by CAFRAM. The specific objectives are (1) to characterize the socioeconomic profile of people living in the periphery of the Tala Tala FMU, (2) to characterize the usages of edible NWFP, (3) to assess the similarities in the use of NWFP, (4) to analyze the relative importance of plants/recipes and the cultural diversity associated to those usages.

\section{Materials and Methods}

\section{Study site}

The Tala-Tala FMU is located in the northern forest sector of Congo, Sangha Division, between $1^{\circ} 16^{\prime}$ $2^{\circ} 12^{\prime}$ latitude North and $14^{\circ} 28^{\prime}-15^{\circ} 52^{\prime}$ longitude East 
(Figure 1). It covers an area of 639.260 ha in the Ngbala, Sembe and Mokeko districts. It is bounded on the north by the Ngoko River, on the south by the Ekouyé River, on the east by the Pandama River upstream to the Léngoué River; downstream to its confluence with the Seka River and to the west by rivers Mambili and Lengoué (CAFRAM 2018).

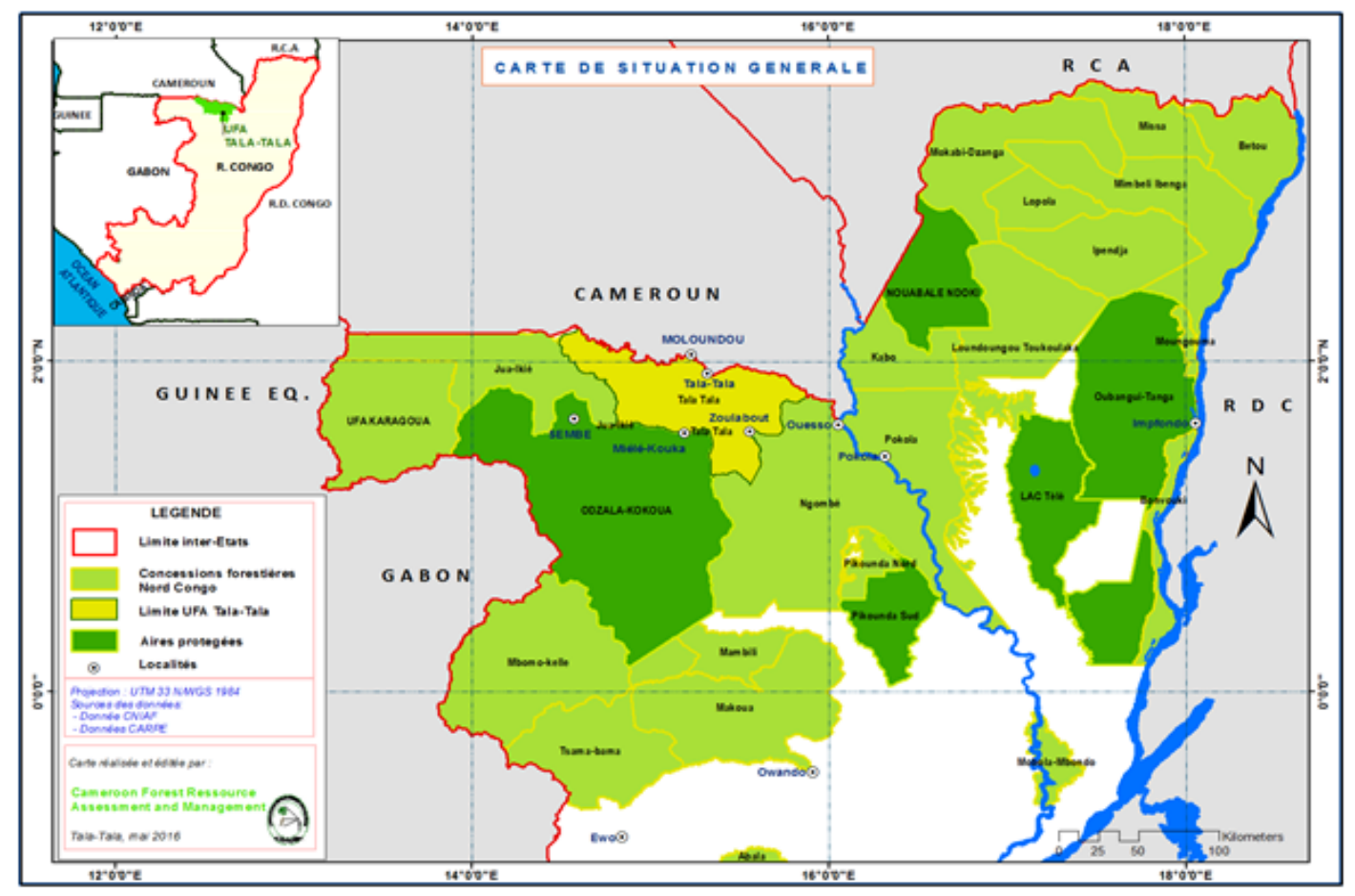

Figure 1. Location map of the Tala Tala FMU in the North Congo (CAFRAM 2018).

The climate is equatorial of the Guinean forest type. It is included in a uniform climatic region stretching from Ouesso to Makoua (North-South) and Souanké to Impfondo (West-East). The rainfall is very abundant reaching 1.600 to $1.800 \mathrm{~mm}$ of water per year. The average monthly temperature is between $24^{\circ} \mathrm{C}$ and $26^{\circ} \mathrm{C}$ and the annual temperature range is $2^{\circ} \mathrm{C}$ to $2.5^{\circ} \mathrm{C}$. The rainy season that runs from March to November is punctuated by a small dry season, from December to March (CAFRAM 2018).

The Planimetric Fund of Central Africa (Sheet NA33-IX, 1968), the Atlas Jeune Afrique of 1997 and the Atlas of the Congo, Phytogeographic Planks of Koechlim et al. (1968) confirm two large types of tall tree formations. The entire Tala Tala FMU is a dense forest, but constituted of many, swampy areas especially along watercourses and degraded forests mainly along the roads that serve the area. The main plant stratum remains the forest. It is mainly forest formations on firm ground, forest formations on swampy land and forest recruits (CAFRAM 2018, Hecketsweiler et al 1991).

Four major ethnic groups populate the area, including Baka, Bakwele, Ndjem, and SanghaSangha. The former belong to the Baka pygmies group, while the three others are bantus people. This population is estimated at about 11.541 inhabitants, found in the chief towns of the districts, and also in the villages along the highways: Mokéko - Sembé, Sembé - Ngbala, Ouesso - Ngbala. This population is supposed to reach 32397 inhabitants by 2047, which is at the end of the first rotation of the forest logging. The main economic activity remains agriculture (CAFRAM 2018).

\section{Ethnobotanical survey}

The method used here and which we call «Method for the popular usage» consists of gathering data on the popular use of forest products in a given area (ex. village). The household was considered as the sampling unit. Data collection consisted of a direct survey on households using NWFP. This was done in two successive phases including interviews and the collection of plant samples. The ethnobotanical survey was conducted from 8 to 23 May 2012 in ninevillage households belonging to three districts based around the Tala Tala FMU including Ngbala, Sembe and Mokeko. The interviews were conducted with households without distinction of sex and age on the popular use of food NWFP. In each household, information could be collected from anyone who was likely to provide useful information on the popular use of edible plants. The sheets containing the interview questionnaire were divided into two main 
parts; the first on the socio-cultural and professional identification of the respondent and the second part on the traditional use of edible plants. For the first part, information was gathered on the name, village, ethnic group, age, sex, and the main function (occupation) of the respondent. For the second part, enquiry was made to know "to what extent food usage (mode of use) was associated to which plant species" rather than asking "which plants were used for which food usages". For each mode of use cited, the name of the plants and the plant parts used were recorded.

The vernacular names of the plants were noted as much as possible, and the plants specimen mentioned by the informants were collected and brought to the National Herbarium of Cameroon, Yaounde. Some plants were identified in the field with the aid of local botanical technicians working at the CAFRAM and SIFCO. Databases on plants taxonomy including LEBRUN and STORK (https://www.ville-

ge.ch/musinfo/bd/cjb/africa/recherche.php?langue=f r), $\quad$ JSTOR (https://plants.jstor.org/compilation/Erythrophleum.iv orense), PROTA (https://uses.plantnetproject.org/fr) and the Plant List (http://www.theplantlist.org/tpl1.1/search?q=)were used for eventual verifications.

\section{Data treatment and analysis}

Differences are made here after between the type of use and recipes. The type of use could be a mouth fruit or appetizer, the main course, the ingredient or spices, water, vegetables, wine, almond paste, and coffee.

a) Mouth fruit: This is a wild fruiter whose fruits are edible. Mouth fruits are plants that are eaten either directly or indirectly after processing outside the main course.

b) Main course: It is the most substantial course of a meal. The main course consists of tubers, caterpillars and mushrooms. They are consumed in the fresh state cut into pieces and steamed.

c) Ingredient: An ingredient is any of the foods or substances that are combined to make a particular dish. They are aromatic substances used to season food. Several organs are used as ingredients (leaves, fruit, seeds, bark and almonds) and can be taken from a single species.

d) Juice: It is a liquid which is the basis of fluids of living organisms.

e) Vegetables: This is a plant or part of a plant used as food. Vegetables are basically prepared from leaves that are usually eaten fresh and cut into small slices. f) Wine: An alcoholic drink made from fermented grape juice. The wines are obtained from the exudates of certain species.

g) Almond paste: Almond paste is made from ground almonds or almond meals and sugar in equal quantity. To obtain the paste, the organs are crushed and kept in paste form for immediate use or later. The organs can also be dried before being crushed

h) Coffee: A hot drink made from roasted and ground seeds of a tropical shrub.

Juice, coffee and wine are grouped as drinks.

A recipe in this paper is an expression composed of three elements: the Latin name of the plant cited, its organ (plant part) and the type of use. We grouped the two first letters of each element to yield a recipe. Hence, the recipe which uses the leaf of Gnetum africanum as a vegetable will be expressed as «Gnafleve» with Gnaf: Gnetum africanum; le: leaf; and ve: vegetable

The Excel spreadsheet was used for data entry and processing. One quotation (or citation) is made up of the name of the informant, the socio-economic information (age, sex, ethnic group, occupation, district, village), the local name of the plant, the scientific name, the organ removed, and the type of use.

For data analysis, we assessed the relative importance, the diversity of the usages, and the similarities of plants and recipes among different groups.

The relative importance of usages, plants or recipes was appreciated through the number of quotations (citations). By comparing the Tala Tala whole population to a forest zone, it is possible to make reconciliations of levels of data collection between the systematic botany and the ethnobotany (botany of societies) as shown in Table 1. This reconciliation distinguishes five levels of data collection presented in descending order as follow : the Forest zone, the bloc, the plot, the plant species, and the individual or stem for the botany in one side and the whole population, the ethnic group, the informant, the plant species, and the quotation for the ethnobotany in another side. The smallest level of analysis for the ethnobotany is the quotation. The population of Tala Tala is composed of several groups (Baka, Bakwélé, Ndjem, and Sanga-Sanga), each group contains several informants, each informant indicates or provides many plant species, and each plant species can be mentioned in several quotations or usages. We therefore assessed the Cultural diversity associated to the use of edible NWFP of the Tala Tala FMU through descriptors that are often used in 
Botany/ecology including density, species richness, diversity indexes, and similarity coefficients.

Table 1. Reconciliation of data collection between botany and the ethnobotany

\begin{tabular}{|c|c|c|}
\hline Level & Botany & Ethnobotany \\
\hline Level 1 & $\begin{array}{l}\text { Tala Tala } \\
\text { Forest }\end{array}$ & $\begin{array}{l}\text { Tala Tala } \\
\text { population }\end{array}$ \\
\hline Level 2 & Forest bloc & Ethnic group \\
\hline Level 3 & Plot & Informant \\
\hline Level 4 & Plant specie & Plant specie \\
\hline Level 5 & $\begin{array}{l}\text { Individual } \\
\text { (stem) }\end{array}$ & Quotation \\
\hline
\end{tabular}

Density (D) of plants/recipes in this study is referred to the ratio of the Number of plants (or recipes) quoted/ number of informants $(D p=n p / l$, or $D r=n r / l$ ; with $\mathrm{np}=$ number of plants, $\mathrm{nr}=$ number of recipes and $I=$ number of informants). Diversity indices used include the Shannon Weaver index, the Simpson index and the regularity or the equitability index of Pielou. The Shannon Weaver index $\left(\mathrm{H}^{\prime}\right)$ allows to assess the diversity level of each group taking into account the proportion of each plant in the group. It is calculated as follow: $H^{\prime}=\Sigma p_{\text {iLog }}(p i)$. In this formula, $\mathrm{Pi}=\mathrm{Ni} / \mathrm{N}$, with $\mathrm{Ni}$ : number of mentions of the plant or recipe $\mathrm{i}$, and $\mathrm{N}$ : total number of quotations for all plants or recipes in the group. The Shannon index is sensitive to the variations of importance of scarce species (Peet 1974). It is equal to zero when there is only one species, and its maximal value is $\log _{2}(\mathrm{~S})$ when all species have the same dominance (Dajoz 2006). The Simpson index (D) measures the probability for two quotations withdrawn randomly from a given group, to belong to the same plant or recipe (Dajoz 2006). It is calculated through the formula $D=\Sigma(p i)^{2}$. The Simpson index is sensitive to the variations of importance of dominant or abundant species (Peet 1974). It reaches its maximal values in monospecific groups and its minimal value when all species (or recipes) have the same dominance. The regularity or the equitability index of Pielou allowed to note the relative mess «disorder» of the population. It measures the diversity level reached by a group compared to its maximal level of diversity. It compares two groups which have different number of individuals (Grall and Coïc 2005) or quotations in our case. The regularity index tends to zero when almost all quotations are concentrated on one single plant species (or one recipe). It tends to 1 when all species (or recipes) have the same abundance. A weak regularity illustrates the importance of a few dominant plant species. The regularity is calculated as follow: $E=H^{\prime} / \log _{2} S$, with $S$ being the total number of species or recipes (Dufrêne and Legendre 1997). The concomitance usage of the three indices including the Shannon, Simpson, and Pielou allows to make a complete analysis of the structure of the communities of plants (Grall and Coïc 2005), the communities of use plants and recipes in this case.

Similarities in the use of plants or recipes among different ethnic groups and districts were assessed at 2 aspects: the qualitative aspect and the quantitative aspect. In the qualitative aspect, the Sorensen's similarity coefficient was used to determine the convergence of the lists of plants between the districts and the two ethnic groups. It is expressed by the following formula:

$$
K=[2 a /(2 a+b+c)] \times 100,
$$

where $a$ is the number of species common to the two groups that we want to compare, $b$ is the number of species cited only in group I, and $\mathrm{c}$ is the number of species belonging only to group II. If $\mathrm{K}>50 \%$, we deduce that the two groups compared have the same floristic lists (Sørensen 1948). In the quantitative aspect in terms of quotations, we use the Bray and Curtis's distance of dissimilarity (DD). It is used to distinguish groups based on the importance of quotations of plants. Let's suppose two groups i and $\mathrm{j}$, using the following species sp1, sp2, sp3; in the same way. The distance of dissimilarity (DD) is expressed by the following formula:

$$
D D=1-(2 W /(A+B)),
$$

where $W=$ the sum of the minimum $(A ; B), A=$ sum of quotation in group $\mathrm{I}, \mathrm{B}=$ sum of quotation in group II. $D D$ varies from 0 to 1 . If $D D$ is less than 0.5 , we say that the two groups use the same plants with the same importance. These groups are said to be close (Bray and Curtis 1987).

\section{Results}

Socioeconomic profile of people using edible Non-wood forest products (NWF) in the Tala Tala FMU

A total of 52 households provided information on the popular use of wild edible plants. This sample consists of 12 women (23.01\%) and 40 men (77\%). The informants are distributed in nine villages, three districts (Mokeko, Ngbala and Sembé) and two ethnic groups namely, the Baka and the Bakwele with 26 informants per group. Informants are mostly composed of hunters (44.2\%) and farmers (38.5\%), with an average age of 41 years (Table 2). A total of 57 plant species and 69 recipes were collected for which a total of 594 quotations (citations) were made. These species are distributed in 46 genus and 33 families. The question here is to verify if the list of the obtained plants and recipes are representative of the edible NWFP used by the Baka and the Bakwélé populations in the Tala Tala FMU? 
Table 2. List of informants interviewed in the periphery of the Tala Tala Forest management unit

\begin{tabular}{|c|c|c|c|c|c|c|c|}
\hline Informant & $\begin{array}{l}\text { Informant } \\
\text { Code }\end{array}$ & Age & Sex & $\begin{array}{l}\text { Ethnic } \\
\text { group }\end{array}$ & Occupation & District & Village \\
\hline Alombo lodie & $\mathrm{Bk} 1$ & 40 & $\mathrm{~F}$ & Baka & farmer & NGBALA & Nkomo \\
\hline Djinga deni & $\mathrm{Bk} 10$ & 60 & $M$ & Baka & hunter & MOKEKO & Paris village \\
\hline Dobo leonor & Bk11 & 53 & M & Baka & farmer & MOKEKO & Paris village \\
\hline Domo mokossa & $\mathrm{Bk} 12$ & 35 & $M$ & Baka & hunter & MOKEKO & Paris village \\
\hline Epala francois & Bk13 & 31 & $M$ & Baka & hunter & MOKEKO & Paris village \\
\hline Mayemba quifano & Bk14 & 25 & $M$ & Baka & hunter & SEMBE & Douma \\
\hline mebongo gerard & Bk15 & 39 & $M$ & Baka & hunter & NGBALA & Tala-Tala \\
\hline Mokenze pauline & Bk16 & 38 & $\mathrm{~F}$ & Baka & farmer & NGBALA & Tala-Tala \\
\hline Moniama angelique & $\mathrm{Bk} 17$ & 50 & $\mathrm{~F}$ & Baka & farmer & NGBALA & Nkomo \\
\hline Ndinga nestor & $\mathrm{Bk} 18$ & 55 & $M$ & Baka & farmer & NGBALA & Nkomo \\
\hline Ngando denise & Bk19 & 50 & $\mathrm{~F}$ & Baka & farmer & MOKEKO & Paris village \\
\hline Assamella prince & Bk2 & 31 & $M$ & Baka & hunter & MOKEKO & Zoulabouth \\
\hline Obaya adalber & Bk20 & 42 & $M$ & Baka & machetteur & NGBALA & Nkomo \\
\hline Samba albert & $\mathrm{Bk} 21$ & 45 & $M$ & Baka & slaughterer & NGBALA & Tala-Tala \\
\hline Sidi remy & $\mathrm{Bk} 22$ & 35 & M & Baka & hunter & SEMBE & Mielekouda \\
\hline Wassitti albert & $\mathrm{Bk} 23$ & 48 & $M$ & Baka & hunter & MOKEKO & Zoulabouth \\
\hline Wenie adraîsse & Bk24 & 34 & $\mathrm{~F}$ & Baka & farmer & NGBALA & Tala-Tala \\
\hline Zalabua serges & $\mathrm{Bk} 25$ & 28 & $M$ & Baka & hunter & MOKEKO & seka limite \\
\hline Zebela prince & Bk26 & 45 & $M$ & Baka & prospector & SEMBE & Komo \\
\hline Bago alain & $\mathrm{Bk} 3$ & 31 & $M$ & Baka & sawyer & NGBALA & Eghaba \\
\hline Balaka & $\mathrm{Bk} 4$ & 40 & $M$ & Baka & hunter & NGBALA & Nkomo \\
\hline Bebey francois & $\mathrm{Bk} 5$ & 42 & $M$ & Baka & prospector & SEMBE & Komo \\
\hline Begua hervé & $\mathrm{Bk} 6$ & 33 & $M$ & Baka & hunter & NGBALA & Tala-Tala \\
\hline Bembe jean & $\mathrm{Bk} 7$ & 44 & $\mathrm{M}$ & Baka & slaughterer & MOKEKO & Zoulabouth \\
\hline Besse gabriel & $\mathrm{Bk} 8$ & 39 & $M$ & Baka & hunter & MOKEKO & seka limite \\
\hline Djengue joseph & $\mathrm{Bk} 9$ & 50 & M & Baka & hunter & SEMBE & Douma \\
\hline Adekara paulin & Bw1 & 38 & $M$ & Bakwélé & hunter & MOKEKO & Paris village \\
\hline Delam Alphonsine & Bw10 & 47 & $\mathrm{~F}$ & Bakwélé & farmer & MOKEKO & Paris village \\
\hline Digoué fride brustol & Bw11 & 23 & $M$ & Bakwélé & hunter & MOKEKO & Paris village \\
\hline Djesson christine & Bw12 & 25 & $\mathrm{~F}$ & Bakwélé & $\begin{array}{l}\text { farmer } \\
\text { traditional }\end{array}$ & NGBALA & Eghaba \\
\hline Doadoa alfred dodé & Bw13 & 68 & $M$ & Bakwélé & healer & NGBALA & Nkomo \\
\hline Dodo audrey & Bw14 & 41 & M & Bakwélé & hunter & NGBALA & Eghaba \\
\hline Domebo chancelia & Bw15 & 21 & $\mathrm{~F}$ & Bakwélé & student & MOKEKO & Paris village \\
\hline Fapassi basile & Bw16 & 28 & $M$ & Bakwélé & farmer & MOKEKO & Zoulabouth \\
\hline Gomebi henri & Bw17 & 35 & $M$ & Bakwélé & hunter & MOKEKO & seka limite \\
\hline Kepe emiliène & Bw18 & 40 & $\mathrm{~F}$ & Bakwélé & farmer & NGBALA & $\begin{array}{l}\text { Eghaba } \\
\text { Mielekouda }\end{array}$ \\
\hline Lakok pauline & Bw19 & 42 & $\mathrm{~F}$ & Bakwélé & farmer & ABE & Mielekouda \\
\hline Akoba armel & Bw2 & 28 & $M$ & Bakwélé & hunter & SEMBE & Mielekouda \\
\hline Messima sylvie & Bw20 & 43 & $\mathrm{~F}$ & Bakwélé & farmer & NGBALA & Eghaba \\
\hline Messo bara fifi & Bw21 & 36 & $\mathrm{~F}$ & Bakwélé & farmer & NGBALA & Eghaba \\
\hline Nguel armand & Bw22 & 24 & $M$ & Bakwélé & hunter & NGBALA & Eghaba \\
\hline Samba jean marie & Bw23 & 41 & $M$ & Bakwélé & prospector & MOKEKO & Paris village \\
\hline Zebegou christian & Bw24 & 48 & M & Bakwélé & hunter & SEMBE & Douma \\
\hline Zebegou giscard & Bw25 & 30 & $\mathrm{M}$ & Bakwélé & carpenter & SEMBE & Douma \\
\hline Zoquabeta achille & Bw26 & 30 & $\mathrm{M}$ & Bakwélé & sailor & NGBALA & Eghaba \\
\hline $\begin{array}{l}\text { Angoabote joseph } \\
\text { julien }\end{array}$ & Bw3 & 67 & $M$ & Bakwélé & farmer & NGBALA & Tala-Tala \\
\hline Awoudou jose & Bw4 & 46 & $\mathrm{M}$ & Bakwélé & teacher & MOKEKO & seka limite \\
\hline Bagwo rodrigue & Bw5 & 30 & M & Bakwélé & trader & MOKEKO & Zoulabouth \\
\hline Botelid fantony & Bw6 & 48 & $\mathrm{M}$ & Bakwélé & hunter & NGBALA & Nkomo \\
\hline Dacek daniel & Bw7 & 68 & $\mathrm{M}$ & Bakwélé & ficher man & NGBALA & Eghaba \\
\hline Dakual jean pierre & Bw8 & 68 & $\mathrm{M}$ & Bakwélé & hunter & NGBALA & Nkomo \\
\hline Dalodila louis & Bw9 & 58 & $\mathrm{M}$ & Bakwélé & hunter & MOKEKO & Paris village \\
\hline
\end{tabular}

To answer this question, we counted the cumulative number of plants and recipes cited by additional number of respondents. The informants were chosen randomly without replacement in groups of 9 . Figure 2 illustrates the change in the number of plant species/recipes to that of informants. The curves can best be approximated equations: $Y 1=22,307 \ln (x)$ 15,974 and $Y 2=17,414 \ln (x)-7,3348$ respectively for plants and recipes, where $Y 1=$ number of plant species, $Y 2=$ number of recipes, and $\mathrm{x}=$ the number of respondents/informants. The coefficients of correlation are $\mathrm{R}^{2}=0.988$ and $\mathrm{R}^{2} 2=0.958$ 
respectively for plants and recipes. Information was obtained from people with various occupations namely: hunters, farmers, fisherman, slaughterer, prospector, carpenter, sawyer, teacher, students, sailor, traditional healer, trader (Fig. 3). The highest number of informants were hunters (44.2\%), followed by farmers (38.5\%). Farmers are equally distributed in the two groups (19.2\%), but hunters are mostly recruited among the Baka pygmies (25\%).

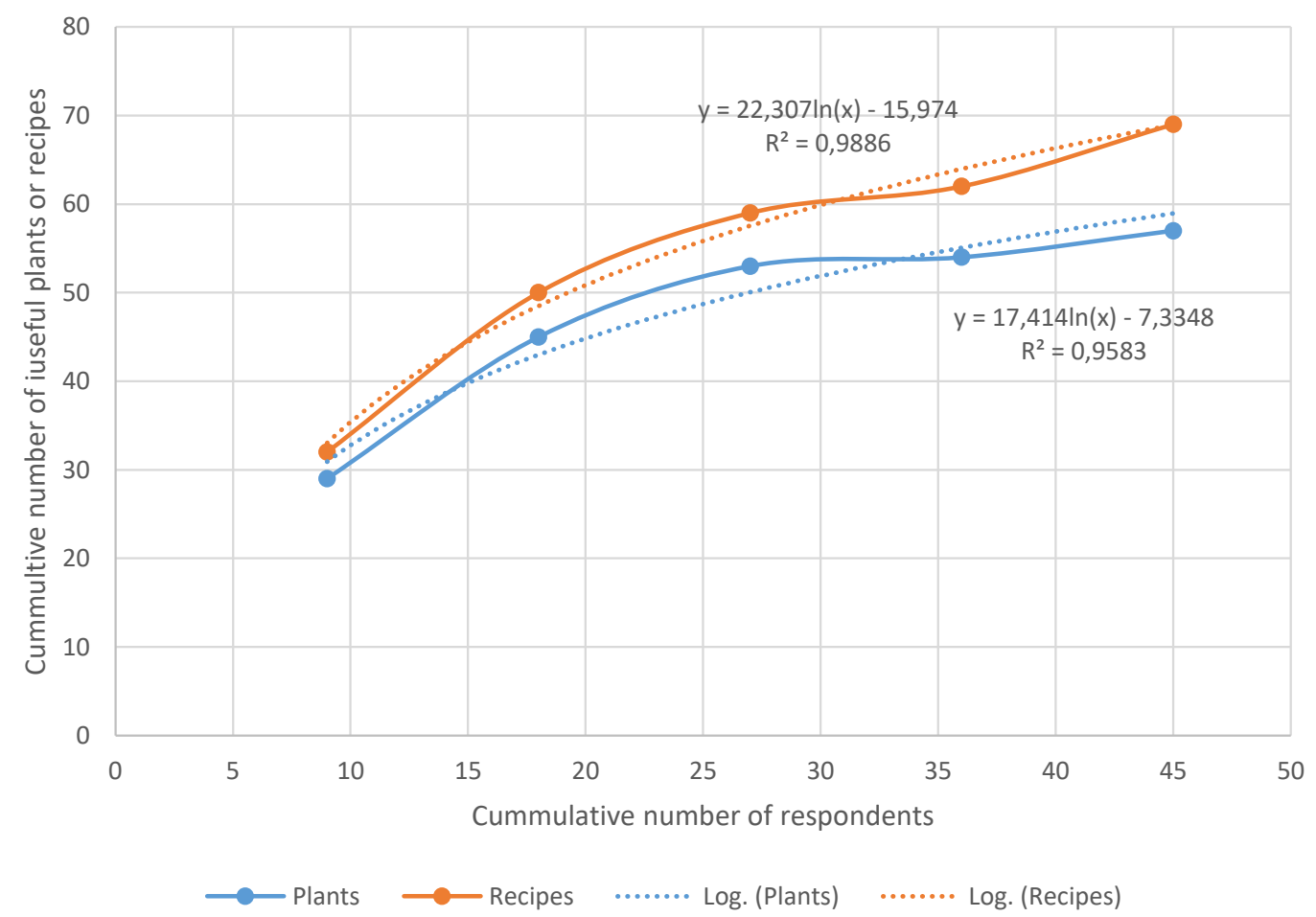

Figure 2. Evolution of number of plants and recipes with the number of respondents (Species-uses curve)

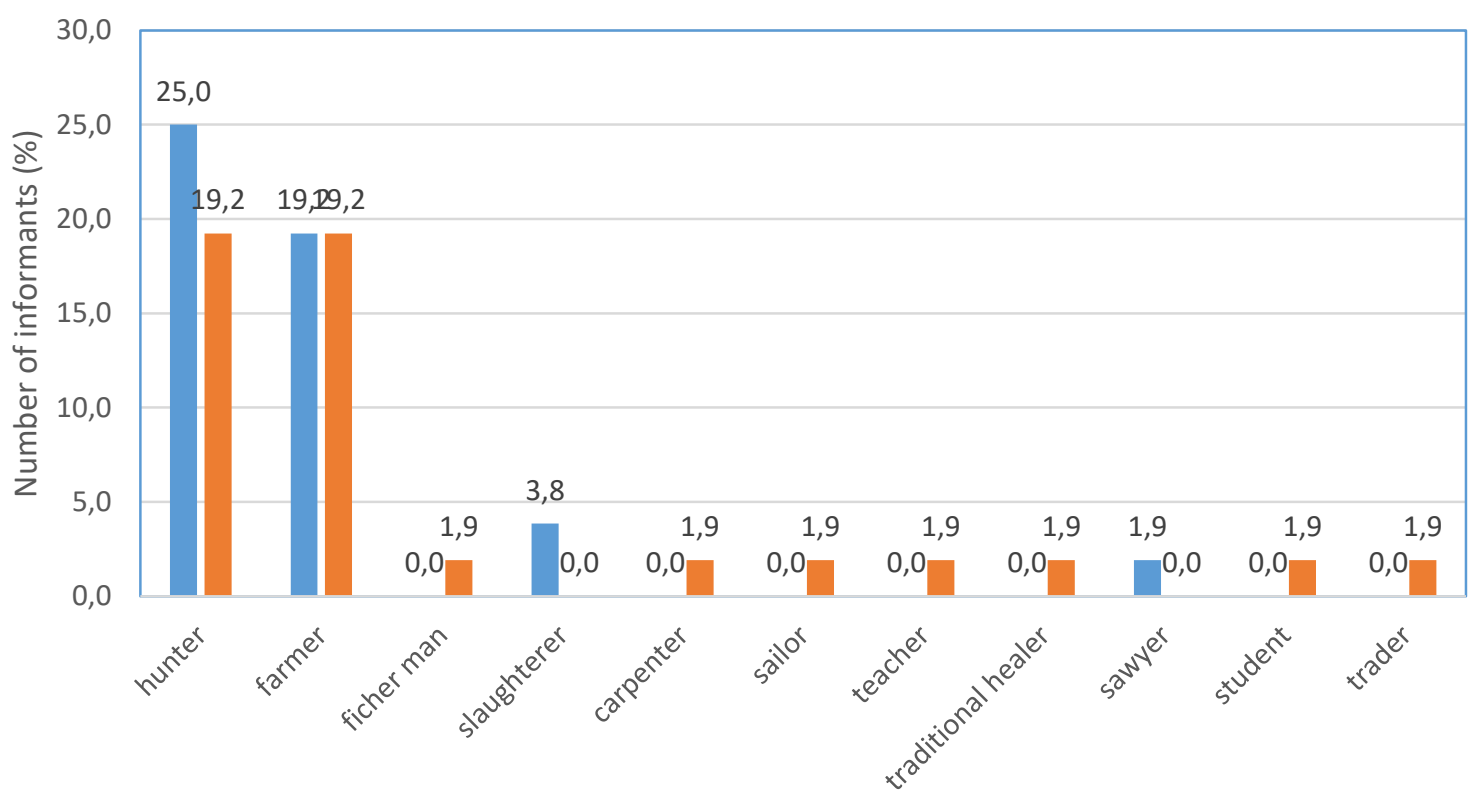

Functions

Baka Bakwélé

Figure 3. Number of informants by occupation 


\section{Characterization of the use of NWFP}

We characterized the usage of plants through the type of plant parts, mode of use and recipes. The various recipes of the plants quoted by the Baka and Bakwélé populations are found in Table 3.

Table 3. List of recipes with quotations

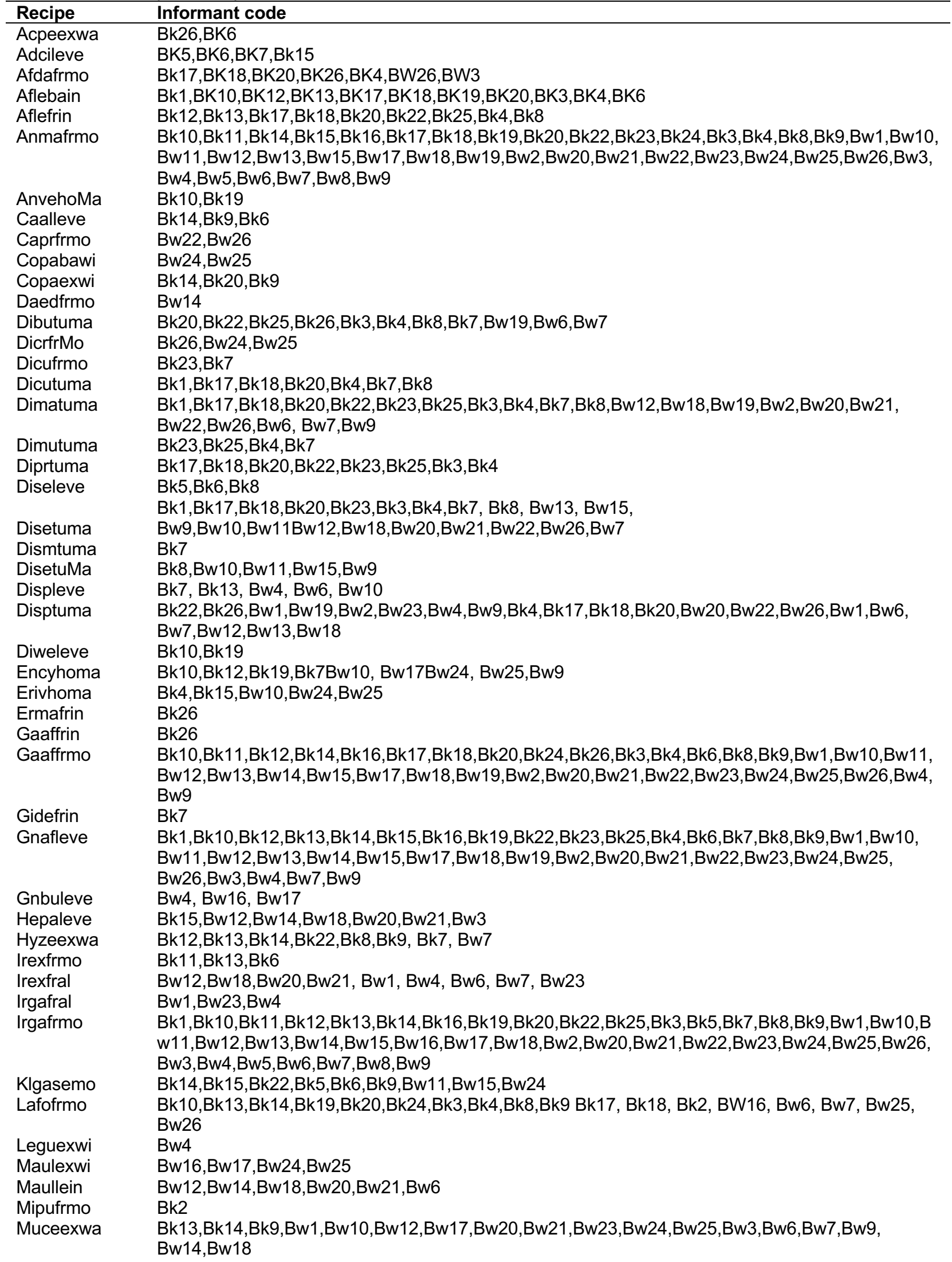




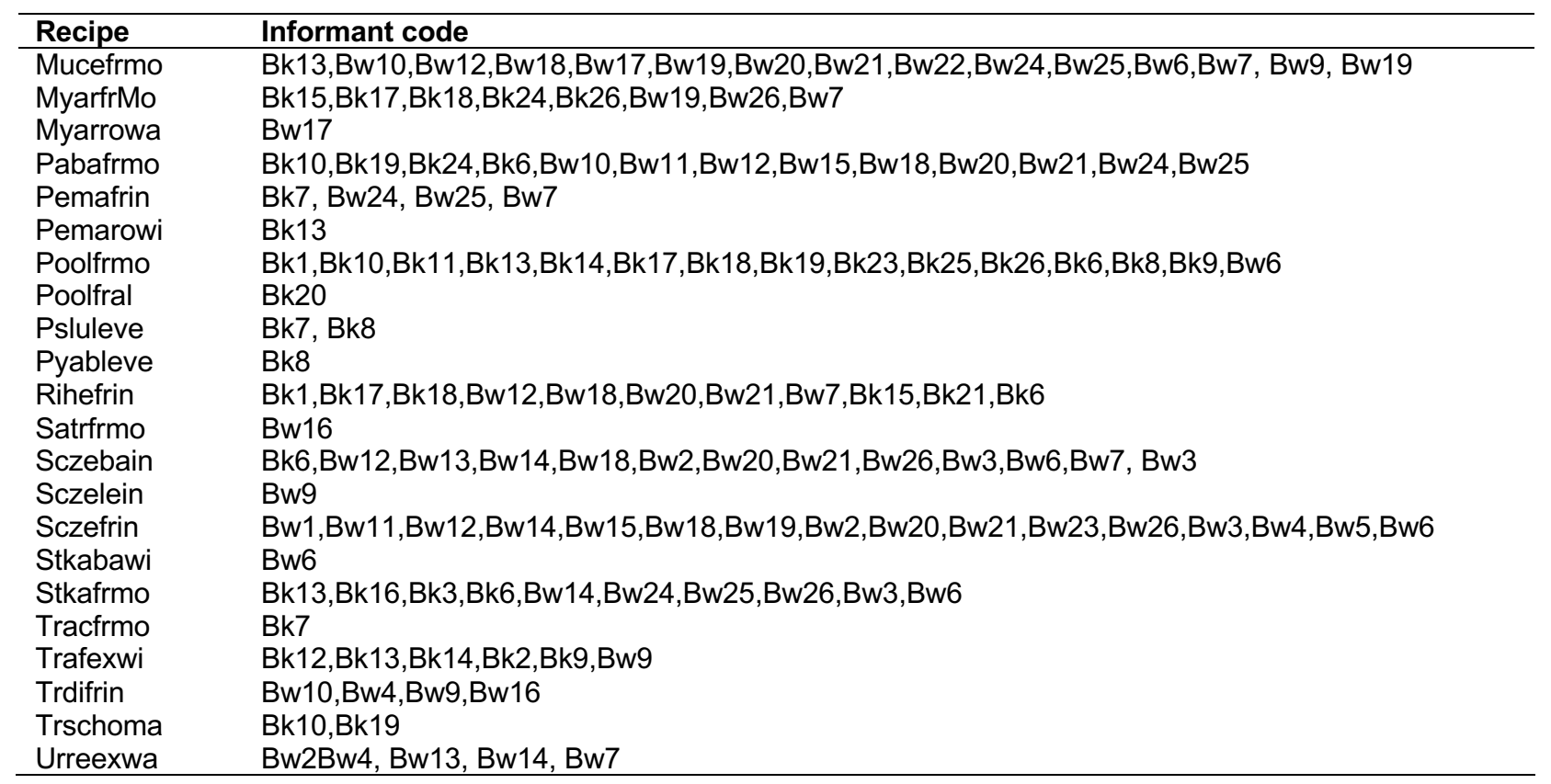

\section{Plant organs}

Seventh types of plant organs were indicated (Fig. 4): fruits (including almonds and seeds), barks, exudates, leaves, host plants, roots, and tubers. Fruits in general are the most used organs with $38.2 \%$ of quotations. They are followed by tubers, $18.6 \%$ and leaves, $14.1 \%$.

\section{Mode of use}

A total of eight types of use were quoted by the Baka and Bakwele namely, mouth fruit, main course, ingredients, vegetables, water, wine, almond paste and coffee (Fig. 5). Plant organs are generally consumed as mouth fruit (39.2\% quotations).

\section{Recipes}

A total of 69 recipes were identified (Table 3). The eleven most used recipes are distributed in five different usages (Fig. 6) including : mouth fruits (Anonidium mannii, Irvingia gabonensis, Gambeya africana, and Klainedoxa gabonensis), main course (Dioscorea sp, D. semperflorens, D. mangenotiana), ingredient (Scorodophleus zenkerii), vegetable (Gnetum africanum), and water (Musanga cecropioides). Two species are largely diversified in terms of recipes including Afrostyrax lepidophyllus (by Baka pygmies) and Scorodophleus zenkeri (both groups) for which leaves, barks and fruits (seeds) are used as ingredients.

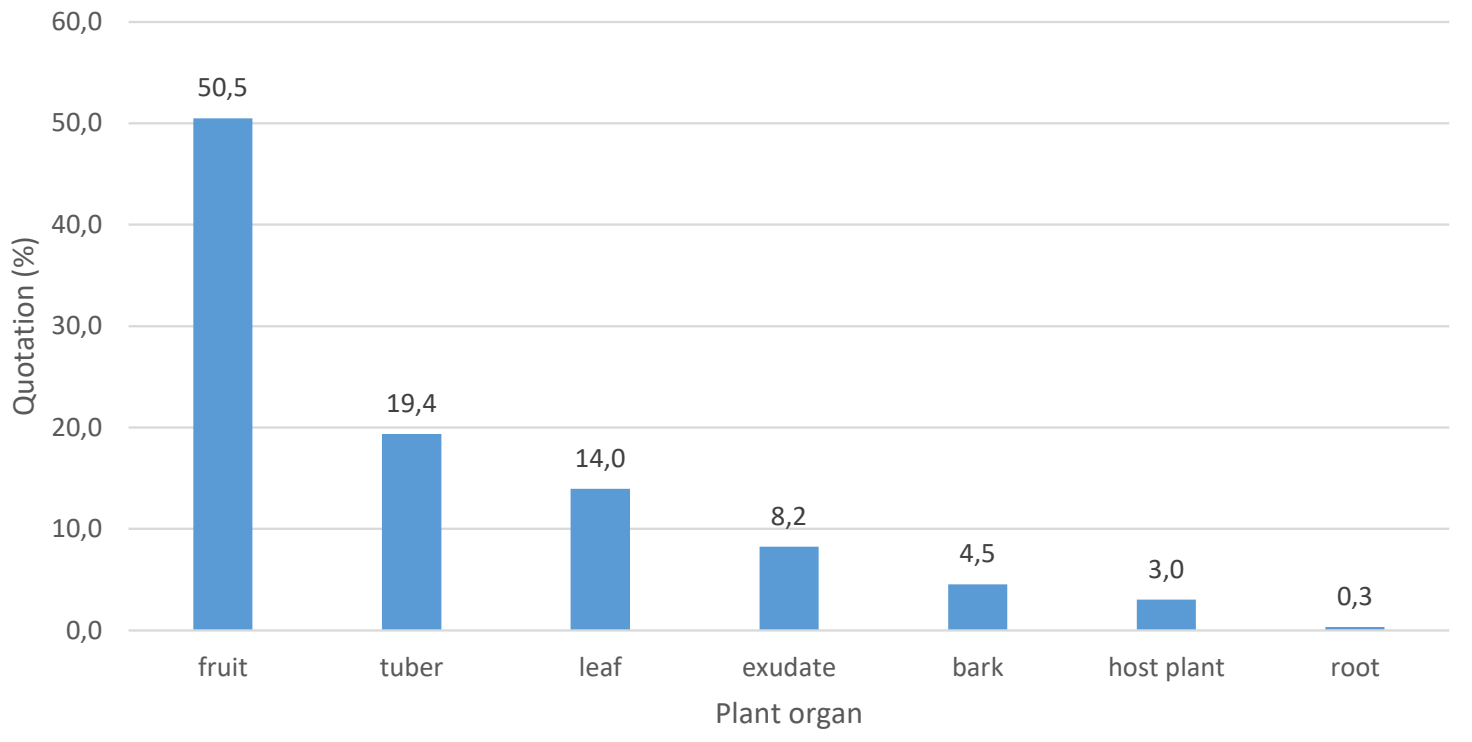

Figure 4. Number of quotations per organ removed. 


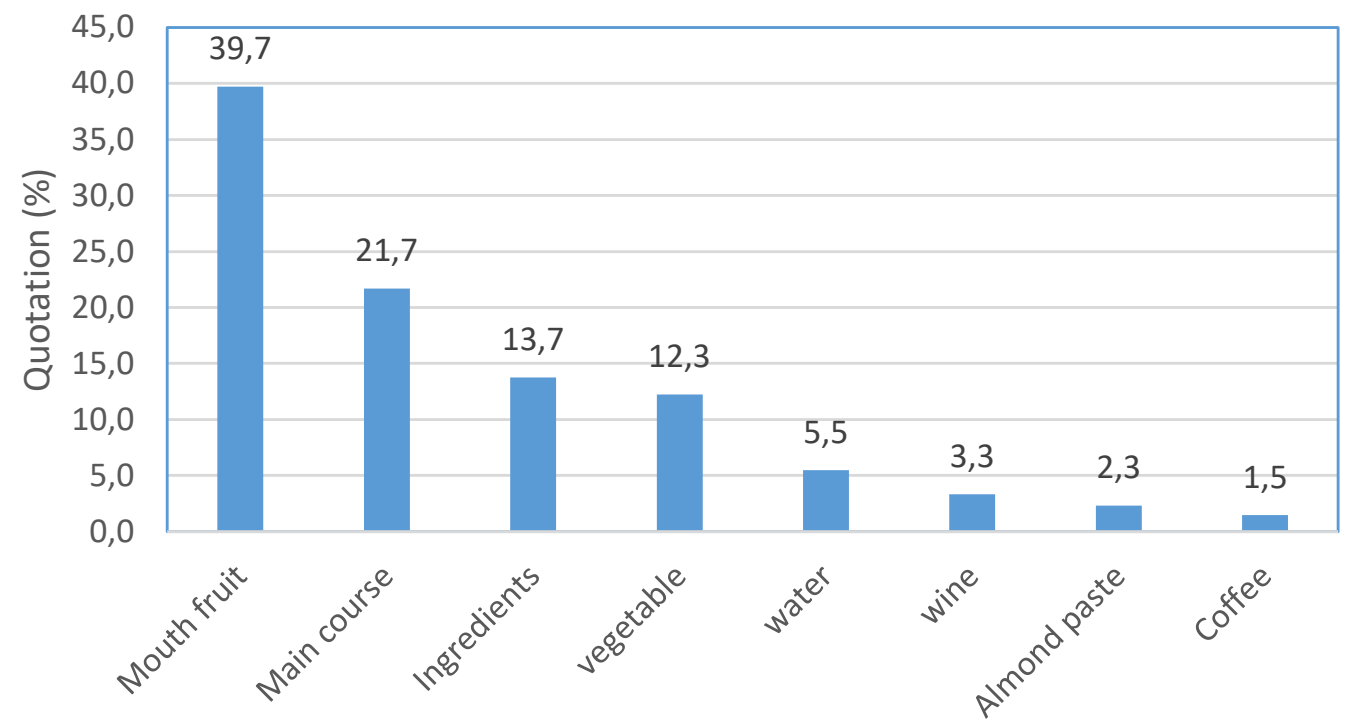

Mode of use

Figure 5. Number of quotations per type of usage

\section{Similarities in the usage of plants and recipes in different groups.}

As stated, similarities in the usages of plants and recipes were examined at two levels, including the qualitative plain (presence/absence) and at the quantitative plain (number of quotations). Tables 4 and 5 present the results of the qualitative similarity analysis for plant species and recipes respectively in different groups. We can see that all the $\mathrm{K}$ values are greater than $50 \%$, which shows that different groups (ethnics and districts) use the same plants and recipes as food.

Table 4. Qualitative similarities between different groups on the floristic list of edible plants. B is the total number of the plant list in group I, $C$ is the total number of plant listed in Group II, a is the common list of plants used by the two groups, $b$ is the proper list of plants for group I and $c$ is the proper list of plants for group II, K is the Sørensen coefficient.

\begin{tabular}{lcccccc}
\hline Plants & B & C & a & b & c & K (\%) \\
\hline Baka/Bakwélé & 46 & 38 & 27 & 18 & 11 & 65 \\
Mokeko/Ngbala & 42 & 39 & 28 & 14 & 11 & 69 \\
Mokeko/Sembé & 42 & 34 & 25 & 17 & 9 & 66 \\
Ngbala/Sembé & 39 & 34 & 29 & 10 & 5 & 79 \\
\hline
\end{tabular}

Table 5. Qualitative similarities between different groups on the list of edible recipes. B, C, a, b, c, and $\mathrm{K}$ defined as above.

\begin{tabular}{lcccccc}
\hline Receipes & $\mathrm{B}$ & $\mathrm{C}$ & $\mathrm{a}$ & $\mathrm{b}$ & $\mathrm{c}$ & $\mathrm{K}$ \\
\hline Baka/Bakwélé & 53 & 47 & 27 & 26 & 20 & 54 \\
Mokeko/Ngbala & 50 & 47 & 30 & 20 & 17 & 62 \\
Mokeko/Sembé & 50 & 39 & 31 & 19 & 8 & 70 \\
Ngbala/Sembé & 47 & 29 & 32 & 15 & -3 & 84 \\
\hline
\end{tabular}

Tables 6 and 7 present the results of the quantitative similarity analysis for plant species and recipes in different groups (ethnic group or districts). We can see that all DD values are less than 0.5 , which shows that different groups (ethnics and districts) use the same plants and recipes with the same importance as food.

Table 6. Quantitative similarities between different groups on the floristic list of edible plants. $A=$ sum of quotation in group $\mathrm{I}, \mathrm{B}=$ sum of quotation in group II, $W=$ the sum of the minimum $(A ; B)$ and $D D$, the dissimilarity distance of Bray-Curtis.

\begin{tabular}{lcccc}
\hline Plants & $\mathrm{A}$ & $\mathrm{B}$ & $\mathrm{W}$ & $\mathrm{DD}$ \\
\hline Baka/Bakwélé & 188 & 295 & 151 & 0.37 \\
Mokeko/Ngbala & 174 & 256 & 161 & 0.25 \\
Mokeko/Sembé & 168 & 87 & 83 & 0.35 \\
Ngbala/Sembé & 247 & 95 & 85 & 0.50 \\
\hline
\end{tabular}

Table 7. Quantitative similarities between different groups on the list of edible recipes. A, B, W, and DD defined as above.

\begin{tabular}{lcccc}
\hline Recipes & $\mathrm{A}$ & $\mathrm{B}$ & $\mathrm{W}$ & $\mathrm{DD}$ \\
\hline Baka/Bakwélé & 182 & 263 & 145 & 0,35 \\
Mokeko/Ngbala & 168 & 227 & 148 & 0,25 \\
Mokeko/Sembé & 153 & 83 & 80 & 0,32 \\
Ngbala/Sembé & 226 & 88 & 81 & 0,48 \\
\hline
\end{tabular}

Relative importance and diversity of plants and recipes among ethnic groups

The relative importance of plants and recipes was appreciated through the number of mentions. Table 8 presents the list of plants with their families and relative importance in different ethnic groups. The most important families in terms of quotations are: 
Dioscoreacea (7 species; 116 mentions), Leguminoseae-Caesalpinioidaea $\quad(4 ; \quad 38)$, Irvingiaceae (3; 77), Moraceae (2; 48), Euphorbiaceae $(3 ; 30)$, and Sterculiaceae $(3 ; 8)$. The most used edible plants among the Baka pygmies include Afrostyrax lepidophyllus $(8.3 \%$ of quotations), Anonidium mannii (6.42\%), Gambeya africana (6.42\%), Irvingia gabonensis (6.04\%), Gnetum africanum $(6.04 \%)$, Panda oleosa $(5.66 \%)$, D. semperflorens $(4.53 \%), \quad D$. mangenotiana (4.15\%), Landolphia foretiana (3.77\%), and Klainedoxa gabonensis (3.4\%). The most used edible plant species among the Bakwélé ethnic group are Dioscorea sp (11.55\%), Irvingia gabonensis (11.25\%), Musanga cecropioides (8.81\%), Scorodophleus zenkeri (8.81\%), Anonidium mannii (8.51\%), Gnetum africanum (8.21\%), Gambeya africana (6.08\%), (D. semperflorens (3.65\%) and D. mangenotiana (3.34\%).

The relative importance of recipes is presented per ethnic group in Table 9. The most used recipes among Baka pygmies include the consumption of fruits of Anonidium mannii (6.42\%), Gambeya africana (6.04\%), Irvingia gaboneneis (8.04\%), Panda oleosa (5.28\%), Landolphia foretiana $(3.77 \%)$, Klainedoxa gabonensis $(3.40 \%)$ as mouth fruits, the use of leaves of Gnetum africanaum $(6.04 \%)$ as vegetable, the use of tubers of $D$. semperflorens $(4.53 \%)$ and $D$. mangenotiana $(4.15 \%)$ as main course, and the use of Afrostyrax lepidopyllus's barks $(4.15 \%)$ or seeds $(3.40 \%)$ as ingredient. In the other side, Bakwélé use more frequently fruits of Anonidium mannii (8.51\%), Irvingia gabonensis (8.51\%), Gambeya africana (6.06\%), Musanga cecropioides (4.26\%) as mouth fruits. They also use the tubers of Dioscorea $s p$. $(10.64 \%)$ and $D$. mangenotiana $(3.66 \%)$ as main course, leaves of Gnetum africanum $(8.21 \%)$ as vegetable, seeds of Scorodophleus zenkeri (4.86\%) as ingredient and exsudates of Musanga ceropioides $(4.56 \%)$ as juice.

Table 8. List of plants with their relative importance of quotations in different ethnic groups.

\begin{tabular}{|c|c|c|c|c|}
\hline Plant species & Family & Baka & Bakwélé & all groups) \\
\hline Acacia pennata auct. & Mimosaceae & 0.75 & 0.00 & 0.34 \\
\hline $\begin{array}{l}\text { Adenia cissampeloides (Planch. ex } \\
\text { Hook.) Harms }\end{array}$ & Passifloraceae & 1.51 & 0.00 & 0.67 \\
\hline $\begin{array}{l}\text { Aframomum daniellii (Hook. f.) K. } \\
\text { Schum. }\end{array}$ & Zingiberaceae & 0.00 & 0.30 & 0.17 \\
\hline $\begin{array}{l}\text { Aframomum giganteum (Oliv. \& } \\
\text { T.Hanb.) K.Schum }\end{array}$ & Zingiberaceae & 1.89 & 0.30 & 1.01 \\
\hline Afrostyrax lepidophyllus Mildbr. & Huaceae & 8.30 & 0.00 & 3.70 \\
\hline Angylocalyx vermeulenii De Wild. & Fabaceae & 0.75 & 0.00 & 0.34 \\
\hline $\begin{array}{l}\text { Anonidium mannii (Oliv.) Engl. \& } \\
\text { Diels }\end{array}$ & Annonaceae & 6.42 & 8.51 & 7.58 \\
\hline Carapa procera DC. & Meliaceae & 0.00 & 0.61 & 0.34 \\
\hline Carpolobia alba G. Don & Polygalaceae & 1.13 & 0.00 & 0.51 \\
\hline $\begin{array}{l}\text { Cola acuminata (P. Bwaterv.) Schott } \\
\& \text { Endl. }\end{array}$ & Sterculiaceae & 0.75 & 0.00 & 0.34 \\
\hline Cola rostrata K. Schum. & Sterculiaceae & 0.75 & 0.61 & 0.67 \\
\hline Corynanthe pachyceras K. Schum. & Rubiaceae & 1.13 & 0.61 & 0.84 \\
\hline Dacryodes edulis (G.Don) H.J.Lam & Burceraceae & 0.00 & 0.30 & 0.17 \\
\hline Dioscorea burkilliana Miège & Dioscoreaceae & 3.02 & 0.91 & 1.85 \\
\hline Dioscorea mangenotiana Miège & Dioscoreaceae & 4.15 & 3.34 & 3.70 \\
\hline Dioscorea munutiflora Engl. & Dioscoreaceae & 1.51 & 0.00 & 0.67 \\
\hline Dioscorea praehensilis Benth & Dioscoreaceae & 3.02 & 0.00 & 1.35 \\
\hline Dioscorea semperflorens Uline & Dioscoreaceae & 4.53 & 3.65 & 4.04 \\
\hline Dioscorea smilacifolia De Wild. & Dioscoreaceae & 0.38 & 0.00 & 0.17 \\
\hline Dioscorea sp. & Dioscoreaceae & 3.02 & 11.55 & 7.74 \\
\hline $\begin{array}{l}\text { Dioscoresphyllum cumminsii (Stapf) } \\
\text { Diels. }\end{array}$ & Menispermaceae & 3.40 & 0.00 & 1.52 \\
\hline Diospyros crassiflora Hiern & Ebenaceae & 0.38 & 0.61 & 0.51 \\
\hline Diplazium welwitschii (Hooker) Diels & Arecaceae & 0.75 & 0.00 & 0.34 \\
\hline $\begin{array}{l}\text { Entandrophragma cylindricum } \\
\text { (Sprague) Sprague }\end{array}$ & Meliaceae & 1.89 & 1.52 & 1.68 \\
\hline $\begin{array}{l}\text { Eriocoelum macrocarpum Gilg ex } \\
\text { Radlk. }\end{array}$ & Sapindaceae & 0.38 & 0.00 & 0.17 \\
\hline Erythrophleum ivorense A. Chev. & $\begin{array}{l}\text { Leguminoseae- } \\
\text { Caesalpinioidaea }\end{array}$ & 0.38 & 0.91 & 0.67 \\
\hline $\begin{array}{l}\text { Gambeya africana (G. Don. ex Bak.) } \\
\text { Pierre }\end{array}$ & Sapotaceae & 6.42 & 6.08 & 6.23 \\
\hline $\begin{array}{l}\text { Gilbertiodendron dewevrei (De Wild.) } \\
\text { Léonard }\end{array}$ & Gnetaceae & 0.38 & 0.00 & 0.17 \\
\hline
\end{tabular}




\begin{tabular}{|c|c|c|c|c|c|c|c|c|}
\hline \multicolumn{3}{|c|}{ Plant species } & Family & Baka & Bak & élé & all groups) & \\
\hline \multicolumn{3}{|c|}{ Gnetum africanum Welw. } & Gnetaceae & 6.04 & & & 7.24 & \\
\hline \multicolumn{3}{|c|}{ Gnetum buchholzianum } & Olacaceae & 0.00 & & & 0.51 & \\
\hline \multicolumn{3}{|c|}{ Heisteria parvifolia Smith. } & Maranthaceae & 0.38 & & & 1.18 & \\
\hline \multicolumn{3}{|c|}{$\begin{array}{l}\text { Hypselodelphys zenkeriana (K. } \\
\text { Schum.) Milne-Redh. }\end{array}$} & Irvingiaceae & 2.64 & & & 1.35 & \\
\hline \multicolumn{3}{|c|}{ Irvingia excelsa Mildbr. } & Irvingiaceae & 1.13 & & & 1.18 & \\
\hline \multicolumn{3}{|c|}{$\begin{array}{l}\text { Irvingia gabonensis (Aub. Lec. Ex } \\
\text { O'R.) Baill. }\end{array}$} & Irvingiaceae & 6.04 & & & 8.92 & \\
\hline \multicolumn{3}{|c|}{ Klainedoxa gabonensis Pierre } & Irvingiaceae & 3.40 & & & 2.86 & \\
\hline \multicolumn{3}{|c|}{$\begin{array}{l}\text { Landolphia foretiana (Pierre ex } \\
\text { Jumelle) Pichon }\end{array}$} & Apocynaceae & 3.77 & & & 1.68 & \\
\hline \multicolumn{3}{|c|}{ Leea guineensis G. Don } & Leeaceae & 0.00 & & & 0.17 & \\
\hline \multicolumn{3}{|c|}{ Manihot utilissima Pohl } & Euphorbiaceae & 0.00 & & & 1.85 & \\
\hline \multicolumn{3}{|c|}{$\begin{array}{l}\text { Microdesmis puberula Hook. f. ex } \\
\text { Planch. }\end{array}$} & Pandaceae & 0.38 & & & 0.17 & \\
\hline \multicolumn{3}{|c|}{ Musanga cecropioides R. Br. } & Moraceae & 1.51 & & & 5.56 & \\
\hline \multirow{2}{*}{\multicolumn{3}{|c|}{$\begin{array}{l}\text { Myrianthus arboreus P. Beauv. } \\
\text { Pachypodanthium barteri (Benth.) }\end{array}$}} & Moraceae & 1.89 & & & 1.52 & \\
\hline & & & \multicolumn{6}{|c|}{ Hutch. \& Dalz. } \\
\hline \multicolumn{3}{|c|}{ Panda oleosa Pierre } & Fabaceae & 5.66 & & & 2.69 & \\
\hline \multicolumn{3}{|c|}{ Pentaclethra macrophylla Benth. } & $\begin{array}{l}\text { Leguminoseae- } \\
\text { Caesalpinioidaea }\end{array}$ & 0.75 & & & 0.84 & \\
\hline \multicolumn{3}{|c|}{ Petersianthus macrocarpus (Beauv.) } & Lecythidaceae & 0.00 & & & 0.17 & \\
\hline $\begin{array}{l}\text { Pseuderant } \\
\text { (Buttner) Lir }\end{array}$ & $\begin{array}{l}\text { mum lud } \\
\text { au }\end{array}$ & icianum & Acanthaceae & 0.38 & & & 0.17 & \\
\hline $\begin{array}{l}\text { Pycnanthus } \\
\text { Excell }\end{array}$ & ngolensi & (Welw.) & Myristicaceae & 0.38 & & & 0.17 & \\
\hline $\begin{array}{l}\text { Ricinodend } \\
\text { ex Heck. }\end{array}$ & 7 heudelc & (Baill.) P. & Euphorbiaceae & 2.26 & & & 1.85 & \\
\hline Santiria trim & a (Oliv.) & ibreville & Burceraceae & 0.00 & & & 0.17 & \\
\hline Scorodophl & us zenke & Harms & $\begin{array}{l}\text { Leguminoseae- } \\
\text { Caesalpinioidaea }\end{array}$ & 0.38 & & & 5.05 & \\
\hline Staudtia ka & runensis & Varb. & Myristicaceae & 0.00 & & & 0.51 & \\
\hline $\begin{array}{l}\text { Tetracarpid } \\
\text { Arg.) Hutch }\end{array}$ & $\begin{array}{l}n \text { conoph } \\
\text { t Dalz. }\end{array}$ & um (Müll. & Euphorbiaceae & 1.51 & & & 1.35 & \\
\hline Treculia afr & na Desc & & Moraceae & 1.89 & & & 1.01 & \\
\hline Trichoscyph & acumina & Engl. & Anacardiaceae & 0.38 & & & 0.17 & \\
\hline Triclisia dict & phylla D & & Merispermaceae & 0.00 & & & 0.67 & \\
\hline Triplochiton & cleroxylo & K. Schum. & Sterculiaceae & 0.75 & & & 0.34 & \\
\hline Urera reper & (Wedd.) & endle & Urticaceae & 0.00 & & & 1.01 & \\
\hline Table 9. List & ecipe & their relati & & Reci & & Baka & Bakwélé & $\begin{array}{c}\text { all } \\
\text { groups }\end{array}$ \\
\hline importance c & quotatio & $\mathrm{n}$ different $\mathrm{e}$ & thnic & Dimı & & 1.51 & 0.00 & 0.67 \\
\hline Recipes & Baka & Bakwélé & all & Diprt & & 3.02 & 0.00 & 1.35 \\
\hline & & & groups & Dise & & 4.53 & 3.65 & 4.04 \\
\hline Acpeexwa & 0.75 & 0.00 & 0.34 & Dism & & 0.38 & 0.00 & 0.17 \\
\hline Adcileve & 1.51 & 0.00 & 0.67 & Disp & & 0.75 & 0.91 & 0.84 \\
\hline Afdafrmo & 1.89 & 0.61 & 1.18 & Disp & & 2.26 & 10.64 & 6.90 \\
\hline Aflebain & 4.15 & 0.00 & 1.85 & Diwe & & 0.75 & 0.00 & 0.34 \\
\hline Aflefrin & 3.40 & 0.00 & 1.52 & Ency & ma & 1.89 & 1.52 & 1.68 \\
\hline Aflelein & 0.75 & 0.00 & 0.34 & Erivh & & 0.38 & 0.91 & 0.67 \\
\hline Anmafrmo & 6.42 & 8.51 & 7.58 & Erm & & 0.38 & 0.00 & 0.17 \\
\hline AnvehoMa & 0.75 & 0.00 & 0.34 & Gaa & & 0.38 & 0.00 & 0.17 \\
\hline Caalleve & 1.13 & 0.00 & 0.51 & Gaa & & 6.04 & 6.08 & 6.06 \\
\hline Caprfrmo & 0.00 & 0.61 & 0.34 & Gide & & 0.38 & 0.00 & 0.17 \\
\hline Coacfrmo & 1.51 & 0.61 & 1.01 & Gna & & 6.04 & 8.21 & 7.24 \\
\hline Copabawi & 0.00 & 0.61 & 0.34 & Gnb & & 0.00 & 0.91 & 0.51 \\
\hline Copaexwi & 1.13 & 0.00 & 0.51 & Hep & & 0.38 & 1.82 & 1.18 \\
\hline Daedfrma & 0.00 & 0.30 & 0.17 & Hyze & wa & 2.64 & 0.30 & 1.35 \\
\hline Dibutuma & 3.02 & 0.91 & 1.85 & Irexf & & 0.00 & 1.22 & 0.67 \\
\hline Dicrfrmo & 0.38 & 0.61 & 0.51 & Irexf & & 1.13 & 0.00 & 0.51 \\
\hline Dicufrmo & 0.75 & 0.00 & 0.34 & Irgaf & & 0.00 & 2.74 & 1.52 \\
\hline Dicutuma & 2.64 & 0.00 & 1.18 & Irgaf & & 6.04 & 8.51 & 7.41 \\
\hline Dimatuma & 4.15 & 3.34 & 3.70 & Klga & & 3.40 & 2.43 & 2.86 \\
\hline
\end{tabular}




\begin{tabular}{lccc}
\hline Recipes & Baka & Bakwélé & $\begin{array}{c}\text { all } \\
\text { groups }\end{array}$ \\
\hline Lafofrmo & 3.77 & 0.00 & 1.68 \\
Leguexwi & 0.00 & 0.30 & 0.17 \\
Maulexwi & 0.00 & 1.52 & 0.84 \\
Maullein & 0.00 & 1.82 & 1.01 \\
Mipufrmo & 0.38 & 0.00 & 0.17 \\
Muceexwa & 1.13 & 4.56 & 3.03 \\
Mucefrmo & 0.38 & 4.26 & 2.53 \\
Myarfrmo & 1.89 & 0.91 & 1.35 \\
Myarrowa & 0.00 & 0.30 & 0.17 \\
Pabafrmo & 1.51 & 2.74 & 2.19 \\
Paolfral & 0.38 & 0.00 & 0.17 \\
Paolfrmo & 5.28 & 0.30 & 2.53 \\
Pemafrin & 0.75 & 0.91 & 0.84 \\
Pemarowi & 0.00 & 0.30 & 0.17 \\
Psluleve & 0.75 & 0.00 & 0.34 \\
Rihefrin & 2.26 & 1.52 & 1.85 \\
Satrfrmo & 0.00 & 0.30 & 0.17 \\
Sczebain & 0.38 & 3.65 & 2.19 \\
Sczefrin & 0.00 & 4.86 & 2.69 \\
Sczelein & 0.00 & 0.30 & 0.17 \\
Stkabawi & 0.00 & 0.30 & 0.17 \\
Stkafrmo & 0.00 & 0.61 & 0.34 \\
Tecofrmo & 1.51 & 1.22 & 1.35 \\
Tracfrmo & 0.38 & 0.00 & 0.17 \\
Trafexwi & 1.89 & 0.30 & 1.01 \\
Trdifrin & 0.00 & 1.22 & 0.67 \\
Trschoma & 0.75 & 0.00 & 0.34 \\
Urreexwa & 0.00 & 1.82 & 1.01
\end{tabular}

Figure 6 illustrates the relative importance of recipes used in all the two ethnic groups. We can see that, the two groups use more frequently fruits of Anonidium mannii (7.6\%), Irvingia gabonensis (7.4\%), Gambeya africana (6.3\%), as mouth fruits. They also use the tubers of Dioscorea sp. (6.9\%), $D$. semperflorens (4.0) and D. mangenotiana (3.7\%) as main course, leaves of Gnetum africanum $(7.2 \%)$ as vegetable.

Table 10 and 11 respectively present diversity parameters calculated for plant species and recipes for the two ethnic groups interviewed. We can note that the overall usage/cultural diversity is high: the global Shanon diversity index is 4.96 for plant species and 5.29 for recipes, while that of Piélou is 0.85 for plants and 0.86 for recipes. The average densities of the usage are 1.05 plants/informant and 1.28 recipes/informant. All those indexes are higher among Baka than Bakwélé.

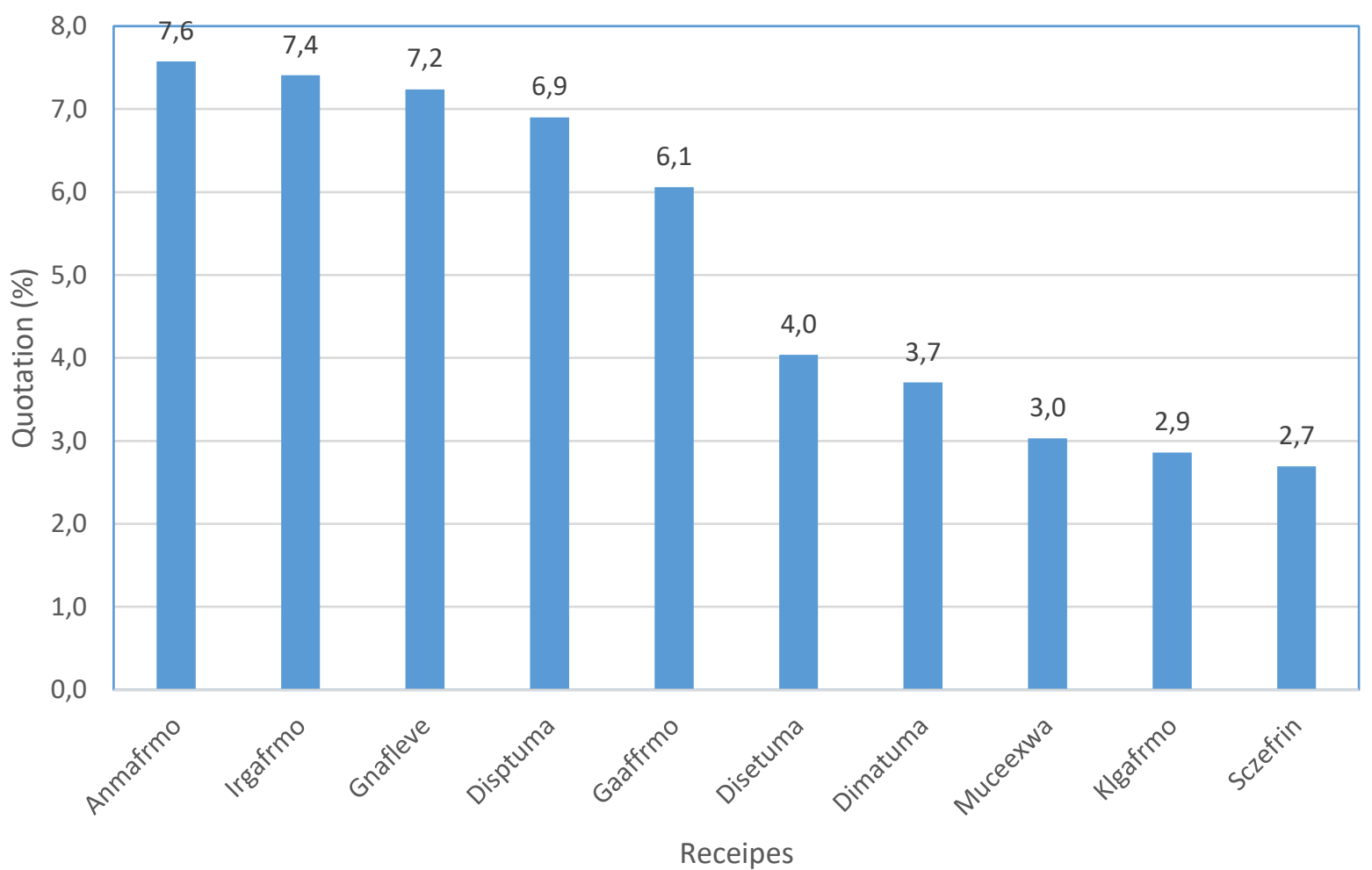

Figure 6 . Number of quotations of the ten most used recipes by the two ethnic groups 
Table 10. Diversity indexes of edible plant species used by Baka and Bakwélé people in the North Congo

\begin{tabular}{lccc}
\hline Diversity parameter & All ethnic groups & Baka & Bakwélé \\
Richness (S) & 57 & 46 & 38 \\
Density & 2.19 & 1.76 & 1.46 \\
Shanon (H) & 4.96 & 4.96 & 4.37 \\
Pielou (€) & 0.85 & 0.89 & 0.83 \\
Simpson (D) & 0.04 & 0.04 & 0.07 \\
\hline
\end{tabular}

Table 11. Diversity indexes of edible recipes used by Baka and Bakwélé people in the North Congo

\begin{tabular}{lccc}
\hline Diversity parameter & All ethnic groups & Baka & Bakwélé \\
\hline Richness (S) & 69 & 53 & 47 \\
Density & 2.65 & 2.03 & 1.8 \\
Shanon $(\mathrm{H})$ & 5.29 & 5.15 & 4.74 \\
Pielou $(€)$ & 0.86 & 0.9 & 0.85 \\
Simpson $(\mathrm{D})$ & 0.04 & 0.04 & 0.05 \\
\hline
\end{tabular}

\section{Discussion}

Socioeconomic profile of people using edible Non wood forest products (NWF)P in the Tala Tala FMU

A total of 57 plant species and 69 recipes were cited, for which a total of 594 quotations (citations) were made on edible NWFP in the periphery of the Tala Tala FMU. This information was cited by 54 people distributed in two ethnic groups including Baka pygmies (26 informants) and Bakwélé people (26). If we consider the current number of people living in the periphery of the Tala Tala FMU and that is estimated at 11.541 inhabitants (CAFRAM 2018), our sampling rate is $0.47 \%$, which is low. Höft et al. (1999) outlined that, the samples collected for ethnobotanical survey are often very poor. The number of informants may not even reach one percent $(1 \%)$ of the total number of persons found in the study site. This is partly because informants are often reluctant to provide information. This makes it quite difficult to define the sampling effort clearly in advance. The sampling effort can easily be appreciated after (at posteriori) through the change in the number of plants-recipes to that of informants. We examined the representativeness of our samples through a regression curve of the number of plant species and recipes by number of informants. Figure 2 shows that the plants and the recipes samples recorded in this study are quite representatives of all that are used by Baka and Bakwélé people living in the periphery of the Tala Tala FMU as edible NWFP. In fact, almost all the wild plants and recipes used for food by Baka and Bakwélé people living in the periphery of the Tala Tala FMU were collected.

The age of the informants varies between 21 and 68 among the 54 respondents, averaging 41 years. Although the villages on the periphery of the Tala Tala FMU have a high proportion of young people, the activities related to NWFP remain secondary because most of them exercise other functions among which hunting (44.2\%) and farmers (38.5 \%).
The main economic activity of people living in the periphery of the Tala Tala FMU remains the agriculture, with the main cash crop being the cocoa, and cassava and banana as food crops. There is a very strong presence of young people between the ages of eighteen and twenty-five in most villages. This situation is explained by (1) the fact that the cultivation of cocoa, well remunerated encourages the clearing of new fields; (2) the presence of forestry companies (SIFCO) which gives the hope of finding work; (3) the trade of gold exploited by rudimentary means; (4) hunting, which is an activity practiced by almost all men still valid; (5) fishing which is not only a source of animal protein but also a source of income. But beyond that, some young people are still migrating in search of jobs towards Ouesso, Brazzaville, Cameroon and elsewhere (CAFRAM 2018).

Farmers are equally distributed in the two groups $(19.2 \%)$, while hunters are mostly found among the Baka pygmies (25\%). This means that those populations, and Baka pygmies to be precise, can no longer be considered only as hunter-gatherers as described in past years (Althabe, 1965 cit. Kitanishi, 2003), but they can be considered as hunter-farmergatherer. A hunter-gatherer is a human living in a society in which most or all food is obtained by foraging (Kitanishi 2003, Yasuoka, 2014). Huntergatherer societies stand in contrast to agricultural Hunter-gatherer, also called forager, any person who depends primarily on wild foods for subsistence. Hunter-gatherers have four general characteristics: (1) they spend several months each year hunting and gathering in the forest; (2) they strongly identify with and prefer forest life; (3) they maintain manystranded social and economic relations with neighboring farming populations; and (4) they practice important ritual activities associated with elephant hunting (Hewlett cit. Yasuoka, 2014). However, considerable diversity has been recorded among the Pygmies. Their subsistence activities have been rapidly changing, and at present, there is 
a large diversity in economic and ecological aspects of their life in the forests. Cultivation by the Pygmies have not been described nor analyzed in any detail. But it is clear that agricultural food is one of the most important energy source for them and that they actually engaged in agricultural work for substantial among of time. The main reasons for these changes may be the impacts of the administrative policy of the colonial and independent governments and the penetration of market economy. Under these circumstances, the Baka gradually accepted cultivation and almost all of them have now their own fields. The Baka gradually sedentarized and began to cultivate in their own fields after the1950s. Because they had been helping the neighboring farmers even before then, they knew how to conduct shifting cultivation (Kitanishi, 2003).

\section{Characteristics of the usage}

There are 57 plant species of food NWFP identified. They are distributed into 36 families and 52 genera. The two ethnic groups interviewed have the same number of informants (26), which allows an intergroup comparison. The life of high proportion of the Congolese population depends on NWFP for food and medicine purposes (Loubelo 2012). Foods gathered from the forest are important sources of nutrients and energy for millions of people in the Congo Basin. Our work reveals the use of 57 plant species as edible NWFP. Fruits and mouth fruits are respectively the most consumed organs $(38.2 \%)$ and types of use (39.2\%). Enquiries conducted by Loubelo (2012) in some markets and localities in the Congo revealed a total of 95 edible NWFP, among which 45 are most cited at local level while 21 are largely used and sold at the national level. Fruits $(45 \%)$ and leaves (38\%) were noted by Loubelo (2012) as the most used plant parts. Same tendances (large use of fruits) were observed in different studies conducted in Cameroon (Betti and Mebere 2011 ; Betti et al. 2016 ; Hamawa 2013 ; Priso et al. 2011 ; Dibong et al. 2011) as well as Côte d'Ivoire (Gautier-Beguin 1992), and in the Democratic Republic of Congo (Mutambwe Shango 2010 ; Termote et al. 2012). The plants largely used in our survey are: Irvingia gabonensis, Dioscorea sp., Anonidium mannii, Gnetum africanum, Gambeya africana, Musanga cecropioides, Scorodophloeus zenkeri, D. semperflorens, Afrostyrax lepidophyllus, D. mangenotiana. Those plants can be considered as the wild edible floristic fund of the Tala Tala FMU. Loubelo (2012) reported that Landolphia sp., Gambeya africana and Treculia africana are among the fruits largely sold in the Congo markets. In their Review of NTFP in Central Africa, Ingram and Shure (2010) compiled a comprehensive list of the status of over 487 forest plants which provide non-timber forest products using five "value" criteria (ranging from $1=$ low to 5 $=$ high) to evaluate the level of consumption, extent and volume of trade, multiple use of a species and use of multiple parts of a species, and the level of vulnerability. Twelve (12) out of the plants cited in that long list, including Gnetum africanum (value 4), Irvingia gabonensis (4), Cola acuminata (4), Baillonella toxisperma (4), Tetrapleura tetraptera (3), Carpolobia alba (3), Aframomum melegueta (3), Aframomum daniellii (3), Panda oleosa (3), Scorodophleus zenkeri (3), Trichoscypha arborea (3) were identified as "priority" or "key", meaning that they were attributed the highest values. The most cited recipes in Tala Tala include the use of Anonidium mannii, Gambeya africana, Irvingia gabonensis, Panda oleosa, Landolphia foretiana, Klainedoxa gabonensis as mouth fruits, the use of Gnetum africanaum as vegetable, the use of tubers of Dioscorea semperflorens and $D$. mangenotiana as main course, and the use of Afrostyrax lepidophullus's barks or seeds as ingredient. Afrostyrax lepidophyllus, Irvingia gabonensis, Gnetum africanum are among the plants most cited in Cameroon (Betti et al. 2016; Sneyd 2013, Ingram and Shure 2010). According to Nkéoua and Boundzanga (1999), the fruits most consumed in Congo are Aframomum, Landolphia, Gambeya africana, Dacryodes edulis. The high consumption of fruit is due to their juicy mesocarp. For them it is the children who, in general, consume the most. On the other hand, in the making of family meals, tubers and leaves are more sought after. They represent respectively about $18.6 \%$ and $14.1 \%$ of the organs frequently consumed. The leaves are the permanent organs on the plants and therefore available all year long. Most often, they serve as a base for soups, stews and also serve as ingredients or spices (Nkéoua and Boundzanga 1999).

Ten types of uses have been described in the Bakwele again nine in the Baka. The two ethnic groups share nine uses in common. The Baka and Bakwele use respectively 7 and 4 species as ingredients. The plant most commonly used to this end by both ethnic groups is Ricinodendron heudelotii. The Ricinodendron almond is extracted from the seeds and then crushed to be used as a thickening ingredient. This use is also described by Eyog Matig et al. (2006), as well as as a flavor enhancer in sauces. The oil of this almond is also suitable for cooking (Tchoundjeu and Atangana, 2006), the manufacture of soap and varnishes (ICRAF 2010). Ricinodendron heudelotii is also reported by N'Dri (1986) and N'guessan (1995) as one of the main food species used in Côte d'Ivoire. Mouth fruits have been described in 18 and 17 species respectively quoted by the Baka and Bakwele. Among these species, 10 species are 
quoted by the two ethnic groups, namely Aframomum giganteum, Anonidium mannii, Cola rostrata, Diospyros crassiflora, Gambeya africana, Irvingia gabonensis, Klainedoxa gabonensis, Myrianthus arboreus, Pachypodanthium barteri, Tetracarpidium conophorum. The importance of fruits or seeds is link to their high nutritive value and also to the facility to conserve the derived products (oils for example). Wild fruits contain vital nutrients (carbohydrates, proteins and minerals) and essential vitamins which are important for the growth of children who are victim of malnutrition and connected diseases (Hamawa 2013). Edible wild fruits play a key role in the wellbeing of rural communities in developing countries, since they replace domestic vegetables during shortage (hungry) periods (Somnasang and Moremo-Black 2000). According to Nkéoua and Boundzanga (1999), wild fruits are essential for a balanced diet in humans, especially in children; rich in vitamin $C$ and mineral salts. Research conducted in the frame of the Bioversity international program in Cameroon revealed that Pentaclethra macrophylla was a rich source of total fat $(38.71 \%)$, protein $(15.82 \%)$ and total fiber (17.10\%) and some bioactive compounds; vitamin E (19.4 mg / $100 \mathrm{~g})$ and proanthocyanins $(65.0 \mathrm{mg} / 100 \mathrm{~g})$. Baillonella toxisperma, had high content of carbohydrates (89.6\%), potassium (27.5 $\mathrm{mg} / 100 \mathrm{~g}$ ) and calcium (37.5 mg / $100 \mathrm{~g}$ ). Flavonoids, polyphenols, vitamins $C$ and $E$ are the main bioactive compounds in these forest foods. The daily consumption of some of these fruits may offer protection against some ailments and oxidative stress (Fungo et al. 2015). The main fatty acids of Baillonella toxisperma oils are oleic, stearic and palmitic acids. The fact that the physico-chemical characteristics and fatty acid profile are comparable to common vegetable oils shows that the $B$. toxisperma oil is a potential source of valuable oil which might be used for edible, cosmetic, pharmaceutical and other industrial applications (Fungo et al. 2017). In Nigeria, Etong and Mustapha (2014) found that the oil of Irvingia gabonensis (African mango) contains six major fatty acid in the following order lauric $>$ myristic $>$ stearic $>$ palmitic $>$ oleic $>$ linolenic acid. The result reveals that the oil extracted can be useful both domestically and industrially. For the main dishes or courses, the Baka and Bakwélé quoted respectively, 8 and 4 edible tuber species, of which 4 species are used by both ethnic groups (Buchcholzia coreacea, Dioscorea sp, $D$. burkilliana, $D$. semperflorens,). The use of other organs of Dioscorea such as young stems (Dioscorea preussii), tips of young stems (Asparagus) and leaves (Dioscorea praehensilis), stems consumed (Dioscorea mangenotiana), edible stalk ends (Dioscorea liebrechtsiana), young leaves (Dioscorea bulbifera) has been mentioned in Congo by Nkéoua and Boundzanga (1999). The Raphiales and Arecales are known by all the people of the Congo Basin as plants producing wines (Nkéoua and Boundzanga 1999). Other plants are used for the production of wines from their exudate and stem bark.

The more a plant is quoted, the more that plant is important. Conciliation between botany or forest ecology and ethnobotany has already been done by several authors (Höft et al. 1999, Betti 2002, Kunwar et al. 2019). Höft et al. (1999) proposed to use similarity indexes including Ochiai Index, Sorensen index and Jaccard index often used in forest ecology to compare groups of respondents/informants in ethnobotany. This can consist on a qualitative plain, of assessing similarity/dissimilarity of people's responses to well defined questions, similarity/dissimilarity of plant utilization patterns among different ethnic, social or gender groups, or similarity/dissimilarity of species based on people's indication of use values. The analysis of the evolution of the cumulative number of useful plants with that of respondents with the aim to assess the representativity of medicinal (Betti 2002) or edible (Betti et al. 2016) plants sold in Yaounde markets in Cameroon was used as a substitute of the " Speciesarea curve » often used in botany or ecology. This evolution is what Kunwar et al. (2019) call the " Species-use curve » on their study of the factors influencing indigenous knowledge of medicinal plant collection and utilization Nepal. The results obtained by Sorensen's similarity index and Bray and Curtis's distance of dissimilarity show that all plants are used by the different ethnic groups with the same importance. The existence of common species for communities living in the same ecological zone highlights the important contribution of the vegetative characteristics of each zone to species diversity and cultural similarity (Abalo et al. 2010). Diversity indexes calculated are high for recipes compared to plant species, which means that the abundance of quotations is more regularly distributed in recipes than in plant species. This can be explained by the difference in number of quotations. In fact, each plant species can be cited in one, two or three recipes. For exemple, Afrostyrax lepidophyllus or Scorodophloeus zenkeri are cited each, in three recipes as ingredients. Diversity indexes obtained for plants and recipes are high among Baka pygmies than Bakwélé population. In other words, the Baka quoted the highest number of plant species $(73.4 \%)$ and recipes $(69.14 \%)$. This indicates that the abundance of plants and recipes is regularly distributed among the Baka pygmies than among the Bakwélé group. This fact illustrates the Baka's reputation as "good masters of the forest and plants 
for food and medicinal purposes" which they enjoy (Nkéoua and Boundzanga 1999, Motte 1980).

\section{Conclusions}

Surveys carried out among Baka pygmies and Bakwélé people living in the periphery of the Tala Tala FMU made it possible to draw up a list of spontaneous 57 edible plants species. There are many convergences of the floristic lists between the surveyed groups. The diversity in the usages of edible plants is most high for Baka pygmies compared to Bakwélé populations. Many edible NWFP used in the North Congo have been reported in other studies conducted in Congo and other African countries. Future studies should consist of structural analysis of the plant species cited with the view to establish their endangerment and to propose fair management schemes.

\section{Declarations}

Ethics approval and consent to participate: Before conducting interviews, prior informed consent was obtained from all participants. No further ethics approval was required.

Consent for publication: This paper does not include any individual person's data and further consent for publication is not required.

Availability of data and materials: Data are available from the authors upon request.

Author contributions: Conceptualization, designing the study and data analysis; Betti Jean Lagarde, Data collection and formal analysis; Billong Fils Pascal Eric, Kourogue Rosine Liliane, Achuo Mbong Faustine, Billong Fils Pascal Eric, Njimbam Njukouyou Oumar Farick.

Conflict of interest: The authors declare that they have no conflict of interests.

Funding: This work was funded by the SIFCO, through CAFRAM. The funding body (SIFCO) itself has no direct role in the design of the study and collection, analysis, and interpretation of data and in writing the manuscript.

\section{Acknocknowledgements}

We thank all people who accept to respond to our questions. The study was conducted with the financial and logistical assistance of CAFRAM and SIFCO.

\section{Literature cited}

Abalo Atato, Wala K, Batawila K, Woegan AY, Akpagana K. 2010. Diversité Des Fruitiers Ligneux Spontanés du Togo. Fruits, vegetable and cereal science and biotechnology. Global Science Book, 4(1):1-9

Anonyme 2005. The Forest Situation of the World Rome $153 p$
Asfaw Z, Tadesse M. 2001. Prospects for sustainable use and development of wild food plants In Ethiopia. Economic Botany, 55: 47-62

Betti JL. 2002. Medicinal Plants Sold in Yaoundé Markets, Cameroon, African Study Monographs, 23 (2): 47-64.

Betti JL, Mebere Yemefa'a SR. 2011. Contribution à la connaissance des produits forestiers non ligneux du parc national de Kalamaloué, Extrême-Nord Cameroun: les plantes alimentaires. International Journal of Biology and Chemical Sciences 5 (1):291303

Betti JL, Belinga SJ, Samba D. 2012. Sustaining Pericopsis elata (Harms) Van Meeuwen in the Tala Tala Forest, North Congo. Global Research Journal of Agricultural and Biological Sciences 3(4):336 -346

Betti JL, Ngankoue Manga C, Dibong Sd, Eboule Singa A. 2016. Etude ethnobotanique des plantes alimentaires spontanées vendues dans les marchés de Yaoundé, Cameroun. International Journal of Biology and Chemical Sciences, 10 (4):1678-1693.

Bray JR, Curtis JT. 1957. An ordination of the upland forest communities of southern Wisconsin. Ecological Monographs 27:325-349.

CAFRAM 2018. Plan d'aménagement de I'UFA Tala Tala, Département de la Sangha, Nord Congo. Document rédigé par le Cameroon Forest Resources Assessment and Management (CAFRAM). P 300.

Dajoz, R. 2006. Précis d'écologie. 8e édition. Paris

Dibong SD, Mpondo Mpondo E, Ngoye A, Priso R. 2011. Inventory and biodiversity of species edible wild fruits sold in the markets of Douala, Cameroon. International Journal of Applied Biology and Pharmaceutical Technology 2(3):303-311.

Dufrêne M., Legendre P.1997. Species assemblages and indicator species: the need for a flexible asymmetrical approach. Ecologcal Monographs 67:345-366.

Etong DI, Mustapha AO. 2014. Physicochemical Properties and Fatty acid composition of Dikanut (Irvingia gabonensis) seed oil. Research Journal of Chemical Sciences, 4 (12):70-74.

Eyog Matig O, Ndoye O, Kengue J, Awono A. 2006. Les Fruitiers Forestiers Comestibles du Cameroun. International Plant Genetic Resources Institute; 204 $P$.

Fungo R, Muyonga J, Kaaya A, Okia C, Tieguhong JC, Baidu-Forson JJ. 2015. Nutrients and bioactive compounds content of Baillonella toxisperma, Trichoscypha abut and Pentaclethra macrophylla from Cameroon. Food Science and Nutrition 3(4):292-301.

Fungo R, Ngondi JL, Muyonga J, Tieguhong JC. 2017. Physico-chemical characteristics and faty acid 
profile of Baillonella toxisperma Pierre traditionally extracted edible oil from Cameroon forests. African Journal of Food, Agriculture, Nutrition and Development 17(4):12758-12774

Gautier-Beguin D. 1992. Etude ethnobotanique des plantes de cueillettes à utilisation alimentaire dans un village au Sud du V-Baoulé (Côte d'Ivoire centrale). Thèse de Doctorat ès Sciences Techniques, mention biologique. Université de Genève, 368 pp.

Grall J, Coic N. 2005. Synthèse des méthodes d'évaluation de la qualité du benthos en milieu côtier. 2006- Ifremer DYNECO /VIGIES/06-13/ REBENT.

Hamawa Y. 2013. Wild edible plants used by Guiziga people of far north region of Cameroon. International Journal of Medicinal and Aromatic Plants 3(2):136143.

Hecketsweilerh P, Doumenge C, Mokoko J, Ikounga J. 1991 Le Parc National d'Odzala Congo. Source: UICN Programme de conservation des forêts. UICNGland Suisse etCambridge Royaume Uni.

Höft M, Barik SK, Lykke AM. 1999. Quantitative ethnobotany. Applications of multivariate and statistical analyses in ethnobotany. People and Plants working paper 6 . UNESCO, Paris.

ICRAF, 2010. Les fruits du succès. Un programme visant à domestiquer les arbres fruitiers sauvages en Afrique occidentale et centrale accroît les revenus de la population, lui assure une meilleure santé et stimule l'économie rurale. Les arbres pour le changement No 4 Nairobi, Kenya. 33P.

Ingram, V, Schure, J. 2010. Review of Non-Timber Forest Products (NTFPs) in Central Africa: Cameroon. Yaounde: CIFOR/FORENET Project. P 177.

Kitanishi, K. 2003. Cultivation by the Baka huntergatherers in the tropical rain forest of Central Africa, African Study Monographs 28:143-157

Koubouana F. 2017. Secteur forestier. Partenariat Public-Privé dans le secteur foresteir au Congo. African Forest Forum, $101 \mathrm{p}$.

Kunwar R M, Shrestha K, Malla S, Acharya T, Sementelli AJ, Kutal D, Bussmann R W. 2019. Relation of medicinal plants, their use patterns and availability in the lower Kailash Sacred Landscape, Nepal. Ethnobotany Research and Applications 18(7):1-14.

Loubelo E. 2012. Impact des produits forestiers non ligneux (PFNL) sur l'économie des ménages et la sécurité alimentaire: cas de la République du Congo. Economies et finances. Université Rennes 2, 2012. Français. ffNNT:2012REN20008ff. fftel-00713758f

Ministry of Forest Economy and Environment 2005. National standards for management inventories of forest resources in the Republic of Congo.
Ministry of Forest Economy and Environment 2004. Forest code of 2000. Editions Hémar, Brazzaville, p. 142.

Motte F. 1980. Les plantes chez les pygmées Aka et les Mozombo de la Lobaye (Centrafrique). Soc. Et. Ling. et Anthrop. de France, Etudes pygmées V, 573 p.

Mutambwe Shango. 2010. Revue Nationale sur les Produits Forestiers non Ligneux (PFNL). Cas de la République Démocratique du Congo. Establishment of Forestry Research Network for ACP Countries (FORENET).

N'Dri P. 1986. Contribution à l'étude de quelques plantes alimentaires spontanées de la région de Divo (Côte d'Ivoire). Mémoire de D.E.A d'Ecologie tropicale Option Végétale. Université de Cocody Abidjan, Côte d'Ivoire, 65 p.

N'guessan K. 1995. Contribution à l'étude ethnobotanique en pays Krobou. Thèse de Doctorat de 3è cycle. Faculté des Sciences et Techniques, Université Nationale de Côte d'Ivoire, Abidjan, 583 pp.

Nkeoua G., Boundzanga G C. 1999. Données sur les Produits Forestiers Non Ligneux en République du Congo. Projet GCP/INT/679/EC PROGRAMME DE PARTENARIAT - EC - FAO (1998-2000) Forestry Statistics and Data Collection - AFDCA/TN/08, 125P.

Peet RK. 1974. The measurement of species diversity. Annual Revue of Ecology and Systematica 5:285-307.

Priso R J, Nnanga J F, Etame J., Din Ndongo, Akoa A. 2011. Les produits forestiers non ligneux d'origine végétale: valeur et importance dans quelques marchés de la région du Littoral - Cameroun. Journal of Applied Bioscience 40:2715-2726.

Rist L, Uma Shaanker R, Milner-Gulland EJ, Ghazoul J. 2010. Traditional ecological knowledge in Forest management, an example from India. Ecology and Society 15:3.

Rist L, Shanley P, Sunderland T, Sheil D, Ndoye O, Liswanti N, Tieguhong J. 2011. The impacts of selective logging on non-timber forest products of livelihood importance. Forest Ecology and Management doi:10.1016/j.foreco.2011.04.037

Sneyd LQ. 2013. Wild Food, Prices, Diets and Development: Sustainability and Food Security in Urban Cameroon. Sustainability 5:4728-4759.

Sorensen T. 1948. A method of establishing groups of equal amplitude in plant sociology based on similarity of species content and its application to analyses of the vegetation on Danish commons. Kongelisk Danske Videnskaops Selskob Biolgisk Sedsckrift Kjöbenhavn 4:1-34.

Somnasang P, Moreno-Black G. 2000. Knowing, gathering and eating: knowledge and attitudes about 
wild food in an Isan village in Northeastern Thailand. Journal of Ethnobiology 20:197-216.

Termote C, Everaert G, Bwama Meyi M, Dhed'a Djailo B, Damme P. 2012. Wild edible plant markets in Kisangani, Democratic Republic of Congo. Human Ecology 40(2):269-285.

Tieguhong JC, Ndoye O. 2007. The impact of timber harvesting on the availability of non-wood forest products in the Congo Basin. Forest Harvest case study 23. FAO, Rome

Tchoundjeu Z, Atangana A R. 2006. Njansang Ricinodendron heudelotii (Baill) Southampton Centre for Underutilised Crops, University of Southampton, Southampton, UK.

Yasuoka 2014. Snare hunting among Baka huntergatherers: implications for sustainable wildlife management. African Study Monographs 49:115136

van Dijk H, Wiersum F. 2004. NTFP resource management as an option for multiple use forest management in South Cameroon. NTFP research in the Tropenbos programme: Results and perspectives. 115-122 